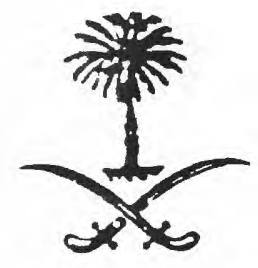

SAUDI ARABIAN MINISTRY

OF AGRICULTURE AND WATER

UNITED STATES

GEOLOGICAL SURVEY

Water Studies Series No. 2

Open-File Report 82-371

\title{
SIMULATED CHANGES IN WATER LEVEL IN THE \\ MINJUR AQUIFER, RIYADH AREA, SAUDI ARABIA
}

James F. Williams III and Ibrahim AI-Sagaby

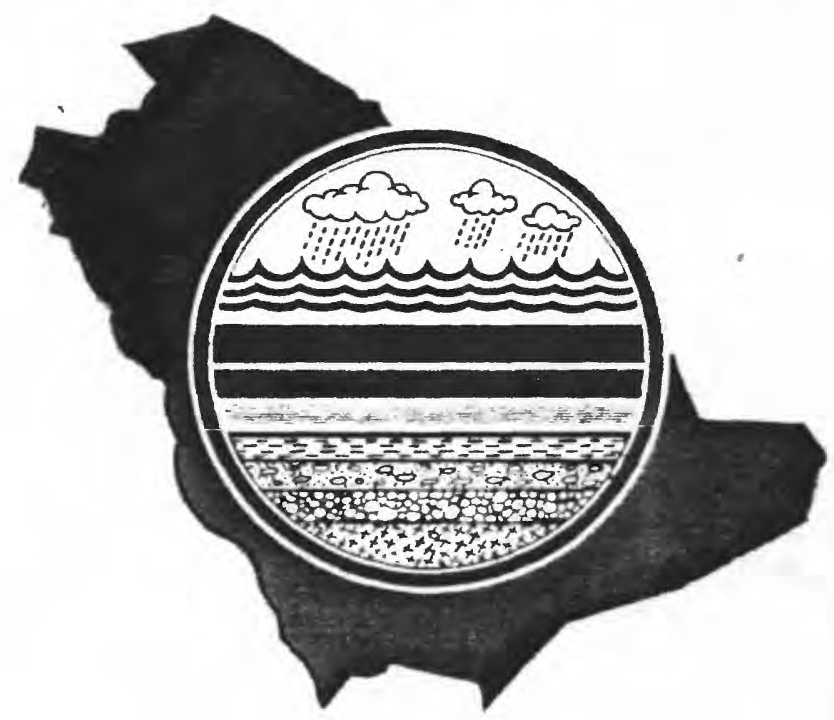

Prepared in cooperation with the United States - Saudi Arabia Joint Economic Commission 


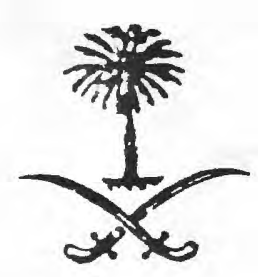

SAUDI ARABIAN MINISTRY

UNITED STATES

OF AGRICULTURE AND WATER

GEOLOGICAL SURVEY

Water Studies Series No. 2

Open-File Report 82-371

\section{SIMULATED CHANGES IN WATER LEVEL IN THE MINJUR AQUIFER, RIYADH AREA, SAUDI ARABIA}

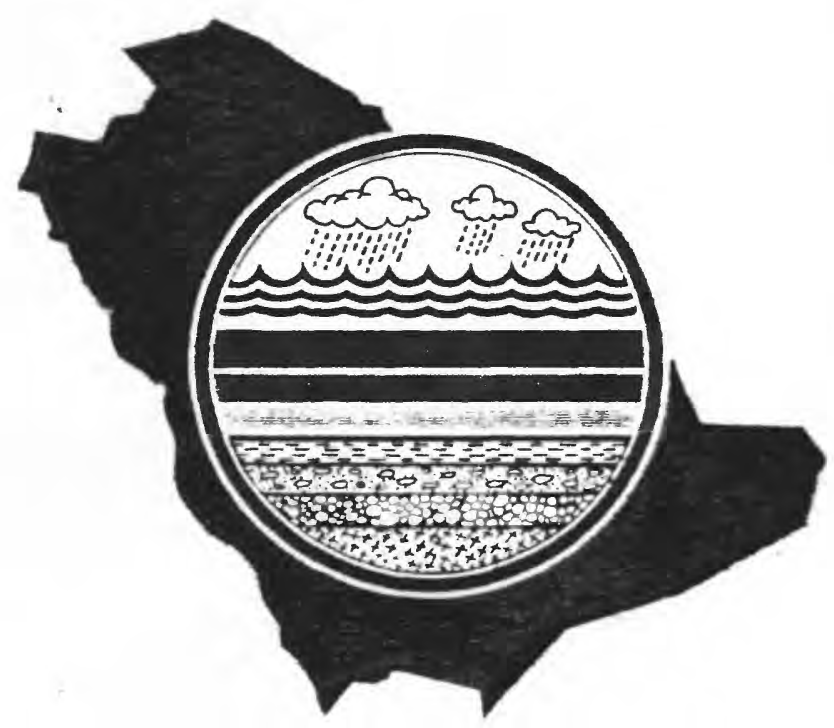

Prepared in cooperation with the United States - Saudi Arabia Joint Economic Commission 


\title{
UNITED STATES DEPARTMENT OF THE INTERIOR
}

JAMES G. WATT, Secretary

GEOLOGICAL SLRVEY

Dallas L. Peck, Director

For additional information write to:

Chief, office of International Activities Water Resources Division

U.S. Seological Survey

470 National Center

Reston, VA 22092

\author{
Kingdom of Saudi Arabia \\ MINISTRY OF AGRICULTURE AND WATER \\ WATER RESOURCES DEVELOPMENT DEPARTMENT \\ Mustafa Noory, Director General
}

For Information write to

Director General, Water Resources Development Department, Ministry of Agriculture and Water, Riyadh

Phone: 401-2777 Extension 808

Date of Issue: $01 / 08 / 1982(12 / 10 / 1402 \mathrm{H})$ 


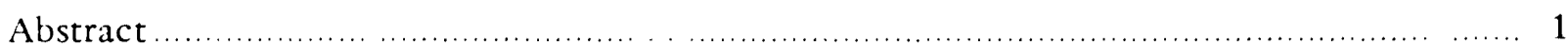

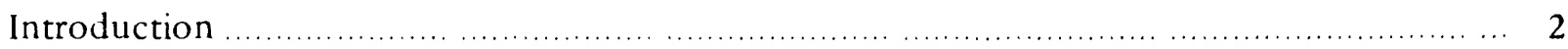

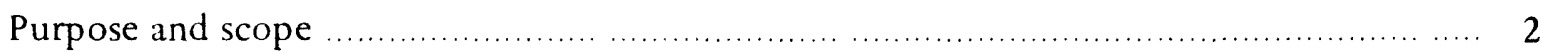

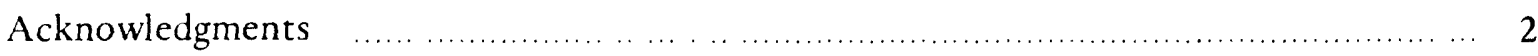

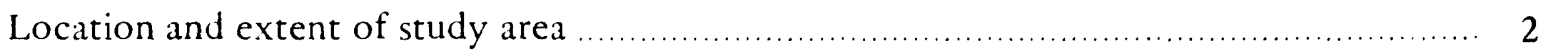

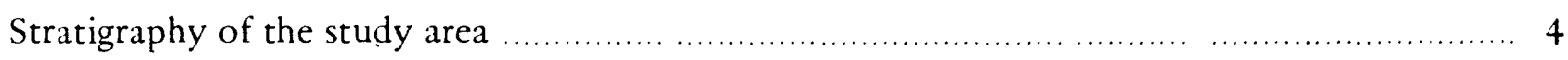

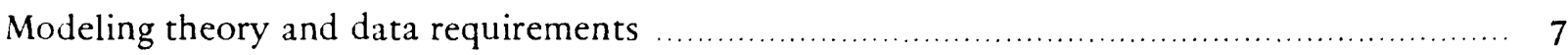

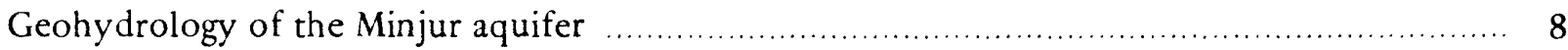

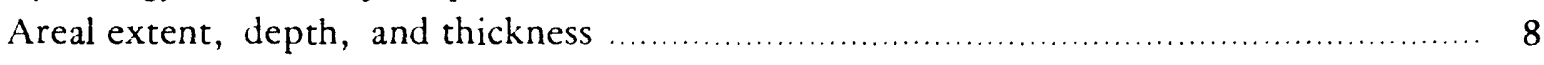

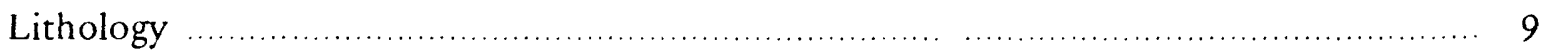

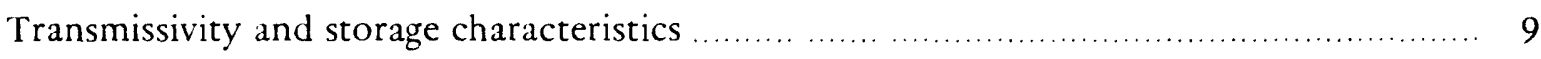

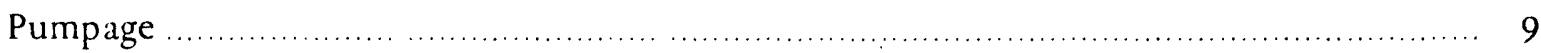

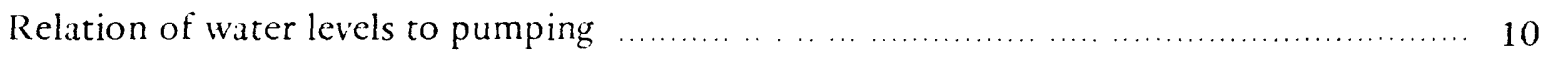

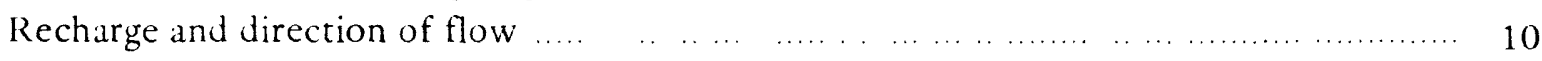

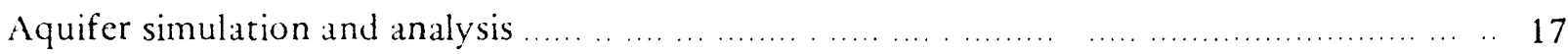

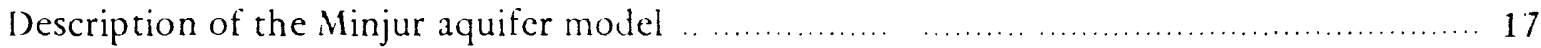

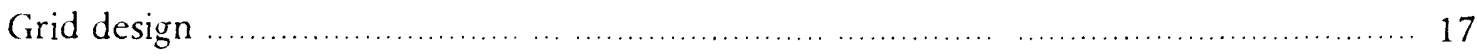

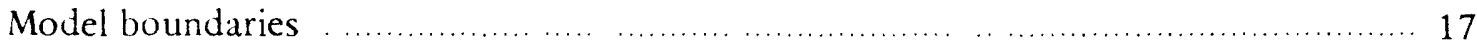

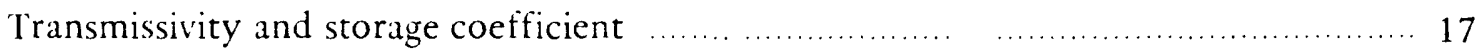

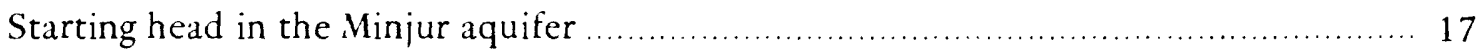

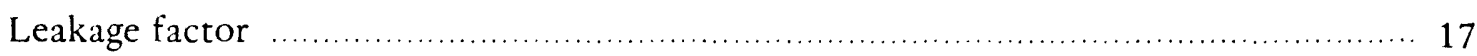

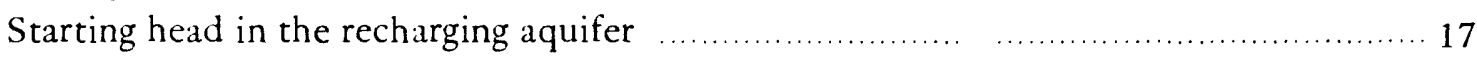

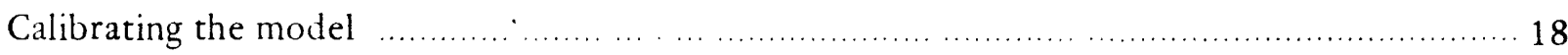

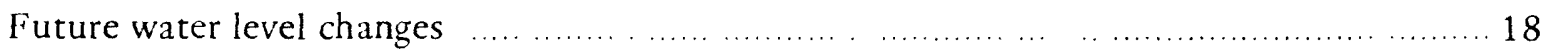

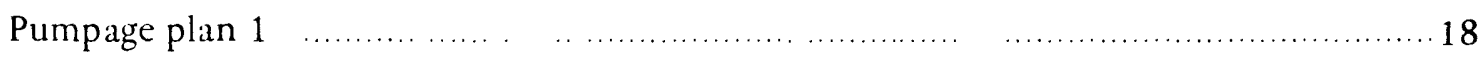

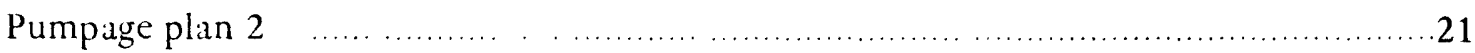

Simulated additional pumping level decline in wells

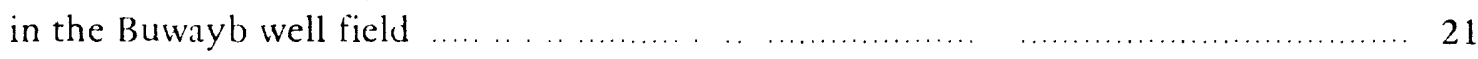

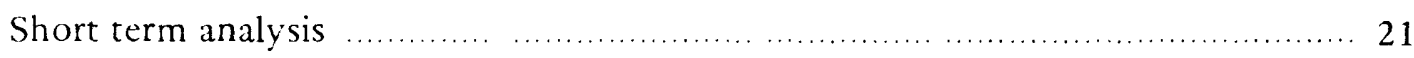

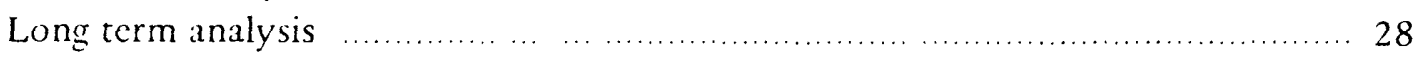

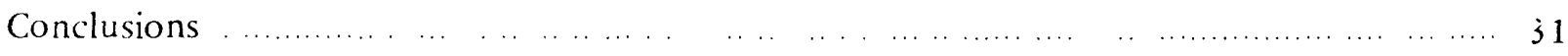

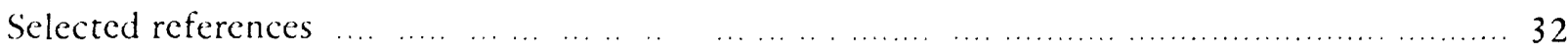

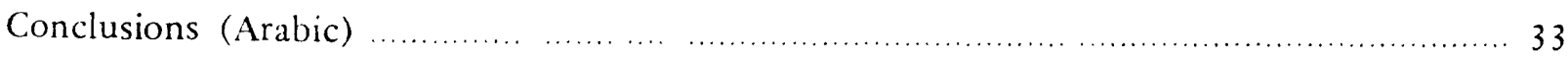

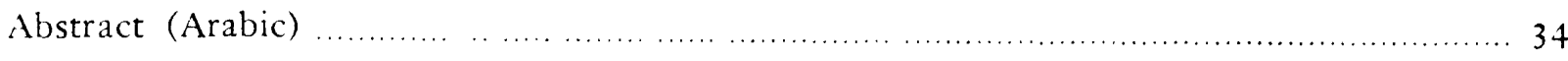


Plate 1 Area, grid spacing, and boundaries used in the digital model of the Minjur aquifer In Pocket

Figure 1. Map of Saudi Arabia showing location of study area 3

2. Generalized subsurface geology of the Arabian Peninsula 5

3. Map showing approximate altitude at the top of the Minjur aquifer In Pocket

4. Map showing approximate transmissivity of the Minjur aquifer In Pocket

5. Map showing location of wells in the Minjur aquifer In Pocket

6. Graph showing pumpage from the Minjur aquifer in the Riyadh area, 1957-1979

7. Map showing approximate prepumping potentiometric surface of the Minjur aquifer

8. Map showing approximate potentiometric surface of the Minjur aquifer, 1974

9. Graph showing estimated future pumping rates for the Minjur aquifer,

Riyadh area

10-13. Map showing predicted water-level decline in the Minjur aquifer using estimated future pumpage plan 1 for the dates

10. $1980-81$

11. $1980-89$

12. 1980-1999

13. 1982-1999

14. Map showing the predicted water-level decline in the Minjur aquifer from 1980 through 1999 using estimated future pumpage plan 2

\section{TABLES}

Table 1. Generalized stratigraphy of the Riyadh Area, Saudi Arabia

2. Major wells in the Minjur aquifer and their estimated pumping rates

3. Comparison of observed and computed water-level changes for 13 wells

4. Comparison of observed and computed water - level changes at National Guard Well \# 1 (Node 35-33)

5. Predicted additional drawdown in selected pumping wells in the Buwayb Well Field (short-term analysis)

6. Predicted additional drawdown in the pumping wells in the Buwayb Well Field (long-term analysis) 


\title{
SIMULATED CHANGES IN WATER LEVEL \\ IN THE MINJUR AQUIFER \\ RIYADH AREA, SAUDI ARABIA
}

by

James F. Williams III* and Ibrahim Al-Sagaby**

\begin{abstract}
A two-dimensional finite-difference computer model of the Minjur aquifer in the Riyadh area of Saudi Arabia was developed to simulate and predict drawdown in the aquifer caused by groundwater withdrawals. The Minjur Formation is of Late Triassic age and is composed of a sequence of sandstones and shales. The sandstones are generally massive, cross-bedded, poorly sorted, and laterally persistent. At Riyadh, the top of the Minjur aquifer is about 1200 meters below land surface. The thickness of the aquifer within the 40,000 square-kilometer study area ranges from 74 to 138 meters inclusively.

The Minjur aquifer is the major source of municipal water for Riyadh, the capital of Saudi Arabia. Without water supplied by the Minjur, it is doubtful that Riyadh could have sustained its enormous growth rate and reached its present population of approximately 1 million. The total pumpage from the Minjur aquifer in Riyadh and its environs has increased from 2,160 cubic meters per day in 1957 to an estimated 220,000 cubic meters per day in 1979 . The Minjur aquifer supplied more than 80 percent of all water used in Riyadh in 1979 .

The Minjur aquifer was modeled as a confined aquifer recharged by leakage through overlying confining beds. The calibration scheme consisted of simulating historical pumpage from an initially flat potentiometric surface. Pumpage was simulated for a 23-year period, 1957 through 1979, and was subdivided into separate pumping periods of 1 -year duration. The model was calibrated by comparing computed with measured water-level decline for various time periods.

Values for aquifer characteristics used in the 160,000-square-kilometer modeled area to represent the Minjur are: Transmissivity of 0.0010 to 0.0062 square meter per second inclusively and storage coefficient of 0.07 and $4 \times 10^{-4}$ for the unconfined and confined sectors, respectively. The value used to represent the vertical conductivity of the confining bed is $2 \times 10^{-12}$ meters per second.

Predictive simulations indicate that if the Minjur aquifer in the Riyadh area were to be stressed by estimated future pumpages, additional water-level declines ranging from 10 to 90 meters, depending on location, would occur in the aquifer from 1980 through 1999. Simulations also demonstrated that pumping levels in the new Buwayb well field will decline substantially from 1980 through 1981.
\end{abstract}

* United States Geological Survey

** Saudi Arabian Ministry of Agriculture and Water 


\section{INTRODUCTION}

The Minjur aquifer is presently the most important water source for the city of Riyadh, the capital of Saudi Arabia. The Minjur, in 1979, supplied over 80 percent of all water used in Riyadh. Without this water it is doubtful that Riyadh could have sustained its present population of approximately 1 million. Approximately 115 large capacity wells presently tap the Minjur aquifer in Riyadh and nearby areas. Combined average daily pumpage in 1979 was about 220,000 cubic meters per day $\left(\mathrm{m}^{3} /\right.$ day $)$.

Since the first production well was drilled into the Minjur aquifer at Riyadh in 1957, increasing ground-water withdrawals have caused progressive declines of ground-water levels. From 1957 through 1979 water-level declines of 75 meters have occurred in the city of Riyadh. Recent heavy withdrawals $\left(100,000 \mathrm{~m}^{3} /\right.$ day during 1980$)$ at the new Minjur well fields north of Riyadh (Salbukh and Buwayb) have caused water-level declines of 85 meters from 1978 to mid 1980.

Because the Minjur aquifer is the only reliable source of a large quantity of chemically acceptable water in the Riyadh area, it will continue to be a major water source for municipalities and large agricultural users. Saudi officials are concerned

\section{Purpose and Scope}

The purpose of this report is to describe a twodimensional model prepared for the Minjur aquifer and to show how the model can be used to predict future water declines resulting from various pumpages. It is useful for water users and managers to know how much drawdown pumpage will cause in an aquifer. Mathematical simulations of an aquifer system and the use of computers has made it possible to estimate changes in the water level of an aquifer based on various pumping arrangements.

\section{Acknowledgments}

The authors would like to express their appreciation to those individuals who contributed their time and effort to this study. Mr. Mustafa Noory, Director General WRDD, was extremely helpful in providing the overall guidance for this investigation. Special appreciation is due Mr. Chase Tibbitts, U.S.-- S.A. Joint Economic Commission, for his ideas related to the general outline of the

\section{Location and Extent of the Study Area}

The Minjur aquifer occurs beneath a large portion of eastern Saudi Arabia. This report is concerned with that part of the Minjur that occurs beneath whether or not the Minjur can continue to supply its share of the projected water needs of the area. The production capability of the Minjur will affect the economic development of the study area. Large increases in population are projected for the Riyadh area and it is necessary to know in advance to what extent the Minjur aquifer can be developed

Because the Minjur aquifer already is heavily used, no new large well fields drilled into the aquifer are planned. A new well field, however, located approximately 120 kilometers $(\mathrm{km})$ east of Riyadh in the Wasia aquifer is under construction. When the Wasia aquifer begins supplying water to Riyadh in late 1981 or early 1982 , it is anticipated that pumpage from the Minjur can be reduced; however, only slight cutbacks are anticipated because water demand will also increase.

Within the Minjur Formation in the Riyadh area, there actually are two aquifers - the upper Minjur and the lower Minjur. These two aquifers are separated by 150 meters of shales and mudstones. The lower Minjur aquifer is unused due to its poor water quality. The upper Minjur aquifer is the focus of this study and henceforth will be referred to as simply the Minjur aquifer unless usage of the term upper Minjur aquifer is deemed necessary for clarification.

Drawdown predictions based on the model may aid water-use administrators and planners in their decision-making process.

All of the available water level and pumpa. records from all wells within the study area as well as every available geological and hydrogeological report of the area were used to prepare and calibrate the model. The finished model was used to simulate future water-level declines based on two different pumping schemes.

report. Historical pumpage values for many of the older wells were provided by Mr. Jesus Quimpo, hydrogeologist, WRDD. Mr. Ali Al-Ddlooj, Director of the Hydrology Division, WRDD, assisted in providing water level information. The tedious job of drafting the plates and figures was executed by Mr. Ghazi Khan, U.S. - S.A. Joint Economic Commission.

the Riyadh area. The study area as defined for this report is approximately square $(240 \times 225 \mathrm{kms})$ with Riyadh located to the south of center (fig.1). 


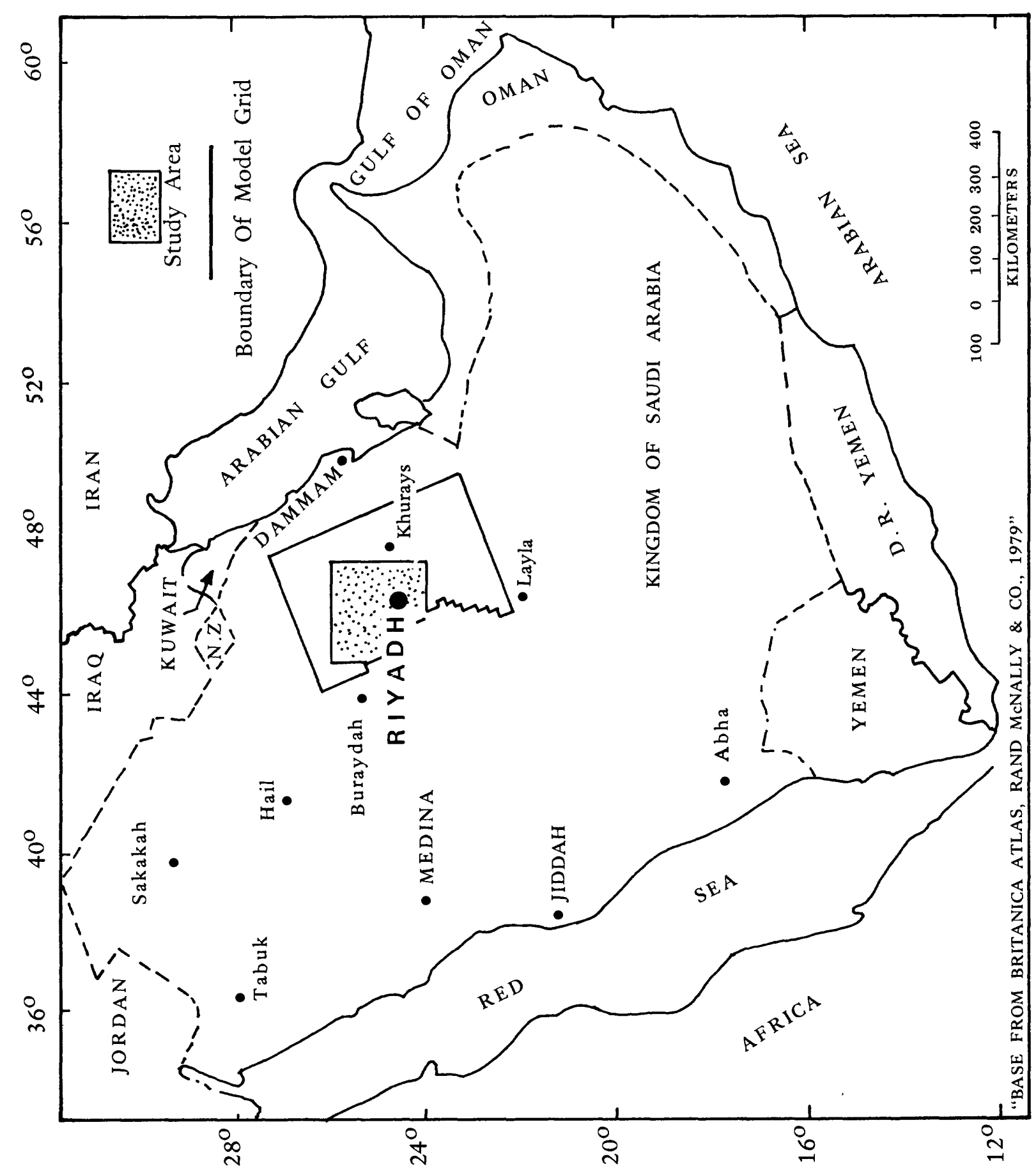

웡 
The study area is approximately 40,000 squar kilometers. Because the model's boundary does not coincide with the study area the total area modeled is approximately 160,000 square kilometers. A more detailed view of the model grid and modeled area is shown on plate 1 .

\section{STRATIGRAPHY OF THE STUDY AREA}

The Minjur Formation is part of a sequence of geologic formations that occur in the Arabian Shelf. The Arabian Shelf is a broad area underlain by an eastwardly thickening wedge of layered beds of limestones, shales, mudstones, and sandstones laid down on a basement complex consisting of crystalline rocks. Figure 2 shows the generalized subsurface geology of the Arabian Peninsula.

Approximately 5,500 meters of sedimentary rocks ranging in age from Cambrian to Pliocene (?) were deposited on the "basement" (Powers and others, 1966, p. 31) in the eastern part of Saudi Arabia. This report focuses attention on one sequence of sandstone layers (upper Minjur aquifer) found in this mass of sedimentary rocks and sediments. Table 1 summarizes the age, lithology, and water bearing properties of all of the various geologic units beneath the study area. 


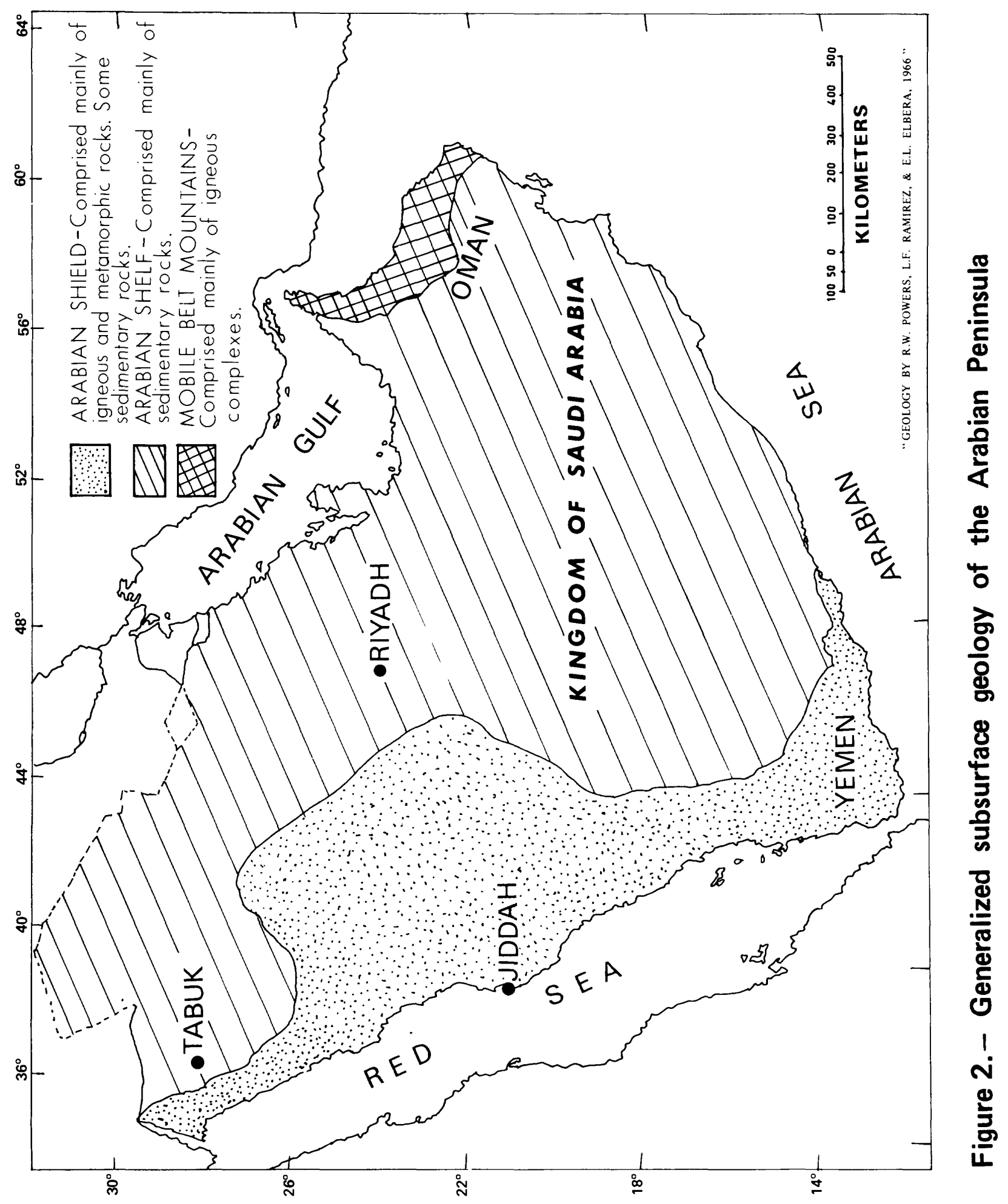




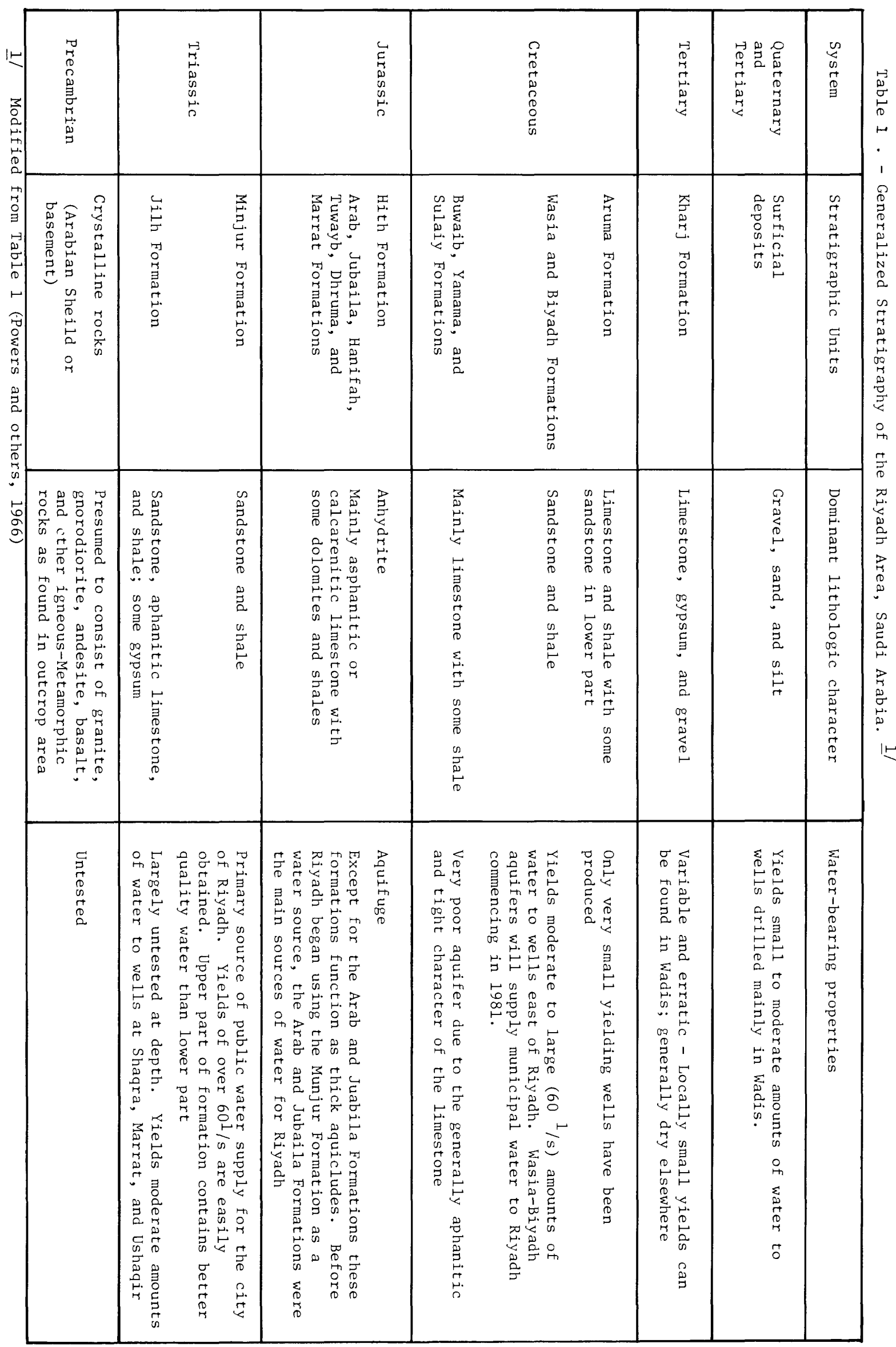


The purpose of the simulation model utilized in this study is to predict the hydraulic head in the Minjur aquifer at any specified location and time.

The theory used in this study is based on the concept that ground-water movement can be expressed in two dimensions as a partial differential equation. The basic flow equation, which is derived by combining Darcy's law and the equation for the conservation of mass, is given by:

(1) $\frac{\partial}{\partial x}\left(T_{x x}-\frac{\partial h}{\partial x}\right)+\frac{\partial}{\partial y}\left(T_{y y} \frac{\partial h}{\partial \bar{y}}\right)=S \frac{\partial h}{\partial t}+W(x, y, t)$

in which

Txx, Tyy $=$ principal components of the transmissivity tensor

(length squared divided by time $\left(\mathrm{L}^{2} \mathrm{t}^{-1}\right)$

$\mathrm{h}=$ height of the ground-water level above an arbitrary reference datum, usually sea level (L);

$\mathrm{S}=$ storage coefficient of the aquifer (dimensionless);

$\mathrm{t}=$ time $(\mathrm{t})$; and

$\mathrm{W}=$ volumetric flux of recharge or withdrawal per unit surface area of the aquifer $\left(\mathrm{Lt}^{-1}\right)$.

Equation 1 can be broken down into finite-difference equations that can approximate the solution to the basic flow equation. The finite-difference equations can be rapidly solved by a digital computer (Trescott and others, 1976). The approximated equation 1 is shown as follows:

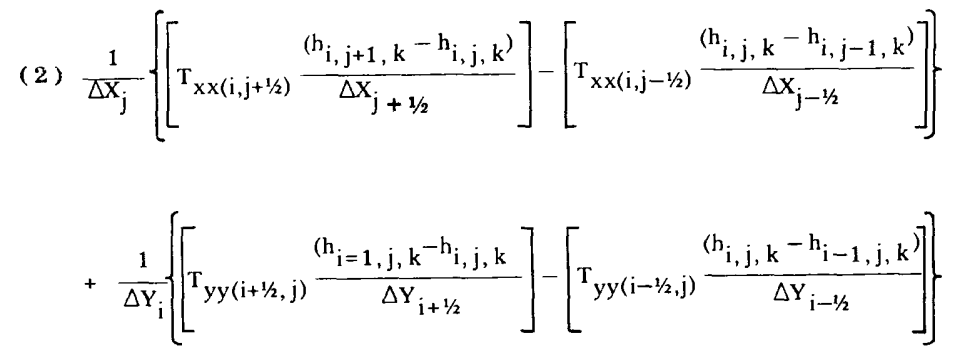

$=\frac{s_{i, j}}{\Delta t}\left(h_{i, j, k}-h_{i, j, k-1}\right)+w_{i, j, k}$ where

$\mathrm{i}, \mathrm{j}, \mathrm{k}=$ indices in the $\mathrm{x}, \mathrm{y}$, and time, $\mathrm{t}$, dimensions; and

$\Delta \mathrm{x}, \Delta \mathrm{y}, \Delta \mathrm{t}=$ increments in the $\mathrm{x}, \mathrm{y}$, and time, $\mathrm{t}$, dimensions.

When the fluxes are comprised of: (1) withdrawals or recharge (for example, evapotranspiration, well pumpage, or well injection), and (2) leakage in or out of the aquifer through a confining bed, then $\mathrm{W}(\mathrm{i}, \mathrm{j}, \mathrm{k})$ in equation 2 is expressed as:

$$
\text { (3) } w_{i, j, k}=\frac{Q_{(i, j, k)}}{\Delta x_{j} \Delta Y_{i}}-\left(h_{i, j, o}-h_{i, j, k}\left(\frac{K_{v(i, j)}}{\left(\frac{\pi K_{v(i, j)}{ }^{t}}{3 M^{2}{ }_{i, j} s_{s(i, j)}}\right)^{1 / 2} M_{i, j}}\right.\right.
$$

$$
\cdot\left\{1+2 \sum_{N+1}^{\infty} \exp \left[\frac{-N^{2}}{\left(\frac{K_{v(i, j)}}{3 M^{2}{ }_{i, j} s_{s(i, j)}}\right)}\right)\right]-\frac{K_{v(i, j)}}{M i, j}-H_{i, j, o}-h_{i, j, o}
$$

where

$\mathrm{H}_{\mathrm{i}, \mathrm{j}, \mathrm{o}}=$ hydraulic head in the aquifer above the confining bed (L);

$\mathrm{h}_{\mathrm{i}, \mathrm{j}, \mathrm{o}}=$ hydraulic head in the aquifer at the

$\mathrm{Kv}_{(\mathrm{i}, \mathrm{j})}=$ vertical hydraulic conductivity of

$M_{i}, j=$ thickness of the confining bed ( $\left.L\right)$;

$\mathrm{Q}_{(\mathrm{i}, \mathrm{j}, \mathrm{k})}=$ rate of withdrawal (positive sign) or recharge (negative sign) $\left(\mathrm{L}^{3} / \mathrm{t}\right)$

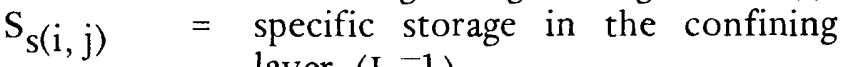
layer $\left(\mathrm{L}^{-1}\right)$;

$\frac{\mathrm{K}_{\mathrm{v}(\mathrm{i}, \mathrm{j})^{\mathrm{t}}}}{\mathrm{M}^{2}{ }_{\mathrm{i}, j} \mathrm{~S}_{\mathrm{S}(\mathrm{i}, \mathrm{j})}}=$ dimensionless time; and

$\mathrm{t}=$ elapsed time of the pumping period (t). 
The digital-model program used for this study is by Trescott and others (1976). It evolved from earlier work by Pinder (1960). The model is designed to simulate in two dimensions the response of an aquifer to an imposed stress.

As in most mathematical models, certain assumptions are presumed to govern the system. The main assumptions of the Trescott, Pinder, and Larson program as they relate to the Minjur aquifer model study are:

1. Flow in the confined aquifer (Minjur) is horizontal and in two dimensions, even though leakage may occur through the upper confining bed. This assumption is justified if the horizontal conductivity is appreciably greater than the vertical conductivity. In addition, the aquifer is assumed to be isotropic and homogeneous within the grid block.

2. Recharge to the Minjur aquifer is derived from leakage through the upper confining material. Hydraulic head in the recharging aquifer is assumed to be constant with time. Any recharge to the Minjur aquifer from below is computed as if it was derived from the upper recharging aquifer.
3. Flow through the confining bed is vertical This assumption is valid if the hydraulic conductivity of the confined aquifer is much greater than the hydraulic conductivity of the confining bed. Experimentally, it has been found that if the ratio of the aquifer's hydraulic conductivity is between $10: 1$ and $100: 1$, the error is 5 percent or less. When the ratio is greater than $100: 1$, the error is less than 1 percent (R.L. Cooley, U.S. Geological Survey, Denver, Colo., written commun., 1976). In this report, the ratio is estimated to be greater than 1,000:1.

The Minjur aquifer was modeled using the Strongly Implicit Procedure (SIP) numerical technique to indirectly solve equation 1 . The outline theory behind the computational algorithm of this method can be found in Remsen, Hornberger, and Milz (1971), and Trescott, Pinder, and Larson (1976).

In order for the model to be a reliable, predictive tool, it must be calibrated against past waterlevel conditions. The procedure used to calibrate the Minjur aquifer model was to simulate historical pumpage and match measured water-level changes against computed values.

\section{GEOHYDROLOGY OF THE MINJUR AQUIFER}

\section{Areal Extent, Depth, and Thickness}

The Minjur Formation crops out on or underlies the entire study area. The Minjur Formation crops out in a NW-SE direction about 100 kilometers west of Riyadh (Fig. 3, in pocket) and occurs at depth to at least as far east as Khurays (plate 1). East of Khurays, the Minjur is believed to become very thin or nonexistent (Brown and Lough, 1963, p. 20). The Minjur Formation (the top of the Minjur Formation is also the top of the upper Minjur aquifer) has been identified on the land surface as occurring between latitudes $20^{\circ} 32^{\prime} \mathrm{N}$ and $28^{\circ} 07^{\prime} \mathrm{N}$, a distance of 820 kilometers (Powers and others 1966, p.D37). Within the study area the outcrop's width varies from less than 10 kilometers, near Shaqra', to approximately 33 kilometers, 70 kilometers southeast of Shaqra'.

The depth below land surface of the top of the Minjur Formation can be determined by subtracting or adding the land altitude to the structure contour lines ( $\mathrm{scl}$ ) of Figure 3. If the top of the Minjur is above sea level then the scl is subtracted from the land altitude to determine the depth below land surface. Conversely, if the top of the Minjur is below sea level then the scl is added to the land altitude to determine the depth below land surface. The top of the Minjur aquifer in the study area varies from approximately 600 meters above sea level in the outcrop area to approximately 1200 meters below sea level at Al Kharj.

The thickness of the Minjur aquifer at Riyadh varies from 105 to 138 meters inclusively. Over half ( 55 percent) of the aquifer's lithology is sandstone, the remainer being interbedded shale. To the northwest of Riyadh in the Jalajil-UshayqirTumair region the thickness of the Minjur ranges from 125 to 132 meters inclusively, and averages 129 meters. At this location the sandstone percentage of total thickness is approximately 50 percent. Near the outcrop area the Minjur Formation thins to an average of 74 meters; however, the percent of sandstone to the total aquifer thickness increases to approximately 70 percent. 
The Minjur Formation is composed mainly of medium-to very coarse sandstone intercalated with subordinate lenses of shale. The sandstones are composed of quartz sands and are generally well sorted. The sand grains show a high degree of rounding and sphericity, typical of a continental deltaic facies. The color of the sandstone typically is white to $\tan$ brown. The porosity of the sandstone is approximately 25 percent (Sir M. MacDonald and Partners, 1975, v. 3, p. 45). The cementation material mainly consists of clay and iron minerals but silica and calcite are present locally in small amounts.

The shales interbedded with the sandstone generally are less than 10 meters thick, are in places fissile or splintery, and appear as varicolored mixtures of green, blue-gray, and red.

\section{Transmissivity and Storage Characteristics}

Transmissivity $(\mathrm{T})$ is the rate at which water of the prevailing kinematic viscosity is transmitted through a unit width of the aquifer under a unit hydraulic gradient. The unit of measure is length squared divided by time. The transmissivity of the Minjur was determined directly by aquifer tests and indirectly from specific capacities. Specific capacity is the relation of yield to drawdown and is given in liters per second per meter of drawdown. In the areas lacking an aquifer test, therefore, the $\mathrm{T}$ was estimated using specific capacity calculated from well completion reports. Not all of the $\mathrm{T}$ values calculated from specific capacity were utilized. Extreme values not fitting the pattern of the majority were not used.

Figure 4 (in pocket) shows the estimated transmissivity of the Minjur aquifer. The areas of highest transmissivity are located to the southeast and west of Riyadh. An area of low $\mathrm{T}$ is situated to the southwest of Riyadh. Transmissivities for areas north and east of the Buwayb well field are guesses as no Minjur wells are present in these areas. Transmissivities are highly approximated also in the outcrop area where few wells have been drilled.

The storage coefficient, as determined by aquifer tests in the confined part of the Minjur aquifer, ranges from $1 \times 10^{-4}$ to $4.3 \times 10^{-5}$ with the average value being $4 \times 10^{-4}$. In the unconfined part of the Minjur aquifer the storage coefficient is less well known but is believed to be approximately 0.07 .
The first well drilled into the Minjur aquifer in the Riyadh area was at Shemesy (Fig. 5 , in pocket). This well was used for municipal purposes and production was commenced in 1957. Before 1957 , all water used in Riyadh was derived from shallow wells constructed to penetrate either the gravel and sand aquifers present in dry stream beds (wadis) or limestones. By the end of 1979, wells in the Minjur aquifer were supplying 80 percent of all municipal water used in the Riyadh area (Abdullah Dahash, Riyadh Water Works, Riyadh, Saudi Arabia, Oral Commun., 1979). In addition, several large farms located to the north of the city of Riyadh (i.e. Faydat er Ritha; Kasha Thamamah) have recently drilled wells which tap the Minjur aquifer. Also, many small towns (Al Majma'ah, Al Kharj, Durma, and others) located to the west and northwest of Riyadh utilize the Minjur as a municipal water source although the quantities pumped are generally small and sometimes pumping is intermittent.

Minjur pumpage in the Riyadh area from 1957 through 1979 is shown in Figure 6. A more detailed breakdown of this pumpage is presented in Table 2 which shows the yearly average pumping rate of each well in the Minjur aquifer in the study area.

Historical pumping rates were difficult to document because records were only partially maintained. Pumpage records for some contemporary wells are even non-existent. Consequently many of the pumping rates used for the model calibration are best-guess estimates. A report by Jesus Quimpo (1972, p.3) was very useful for estimating historical pumpages. 
Before 1957, the Minjur aquifer had not been pumped in the Riyadh area. Hence the aquifer was essentially in a steady state condition. Figure 7 is a computer estimate of the prepumping potentiometric surface of the Minjur aquifer (Papadopulos and others, 1977, p. A-7). Water in the prepumping period moved from the outcrop area toward the northeast. When pumping commenced in 1957, water levels in the aquifer started declining. Figure 8 shows the approximate 1974 potentiometric surface of the Minjur aquifer (Sir M. MacDonald and Partners, 1975, Album of maps and drawings, p.H1). By 1974, 17 years of production had caused water levels to decline about 60 meters in the center of Riyadh. Since 1974, additional water withdrawals from the aquifer associated with the new Salbukh and Buwayb well fields have caused greater water level declines in the Riyadh Area. From 1978 through 1979, water levels declined from 65 to 85 meters inclusively, in the Salbukh field. In the Buwayb field between late 1979 and mid 1980, water level declines of 40 to 65 meters inclusively, took place. In the city of Riyadh, water levels declined an additional 15-25 meters from 1974 through 1979.

\section{Recharge and Direction of Flow}

The Minjur aquifer receives its recharge directly from precipitation and from other aquifers. Precipitation was not incorporated into the Minjur model because of the type of calibration procedure used to model the aquifer. However, the actual amount of direct recharge is believed to be between 3.5 and $7 \mathrm{~mm}$ per year (Sir M. MacDonald and Partners, 1975 , v.3, p. 122).

The Minjur also receives recharge from other aquifers through semi-permeable confining materials. This occurs when the head differential between the Minjur and aquifer below or above is great enough to induce water to leak through the semi-confining material separating the aquifers. The Minjur aquifer is believed to receive most of this type of recharge from deeper aquifers (Lower Minjur, Jilh) rather than from the more shallow aquifers.

In the horizontal direction, ground-water generally moves at right angles to potentiometric contours and from contours with high values to those with lower values. Figure 7 shows the estimated potentiometric surface of the Minjur aquifer before pumping. Ground-water movement was from the outcrop area to the northeast.
When an aquifer is heavily pumped, the withdrawal of water alters the natural flow pattern. For example, Figure 8 shows that by 1974, heavy Minjur withdrawal at Riyadh has caused groundwater movement in the aquifer to reverse its natural flow pattern and develop a new flow system with movement toward Riyadh. 


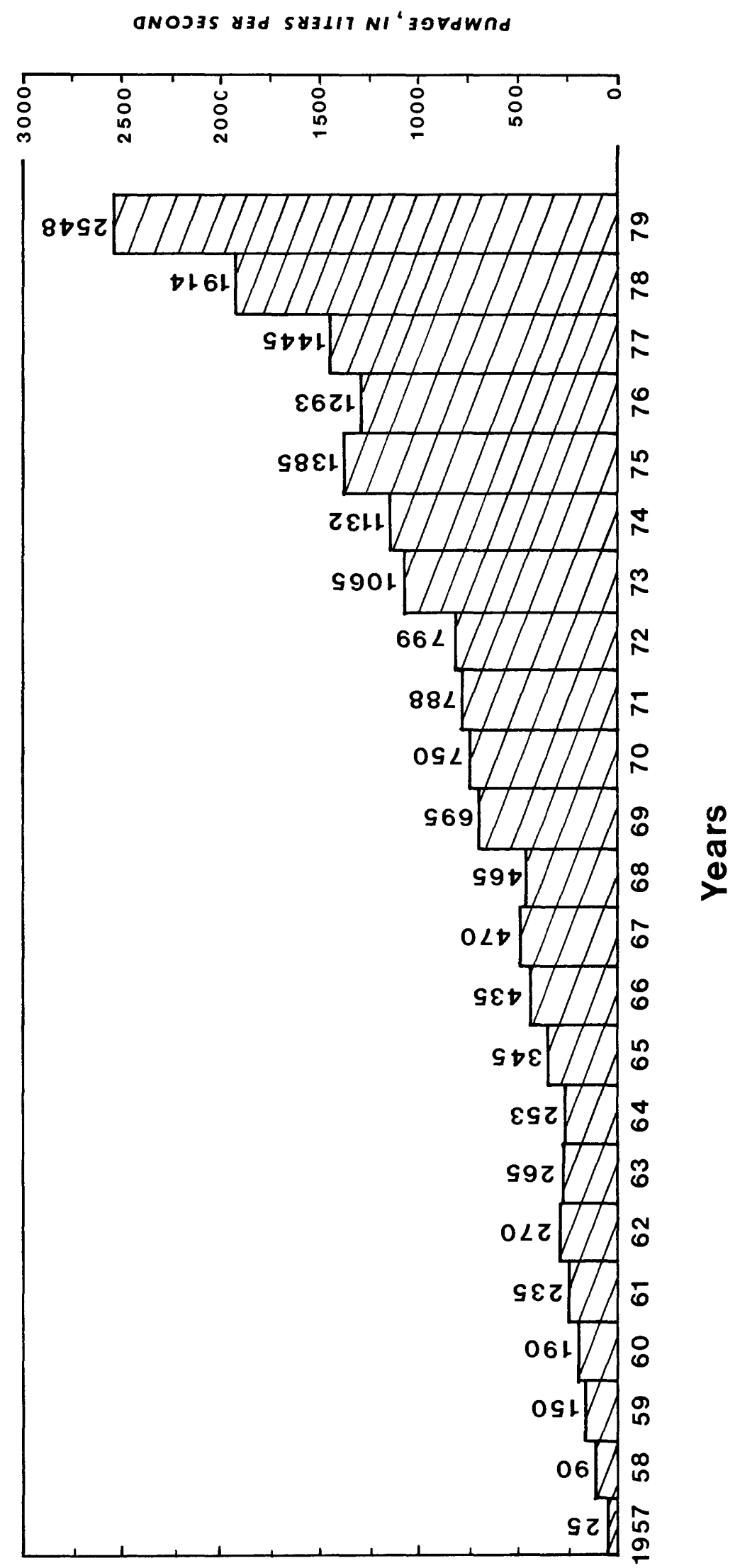

告 


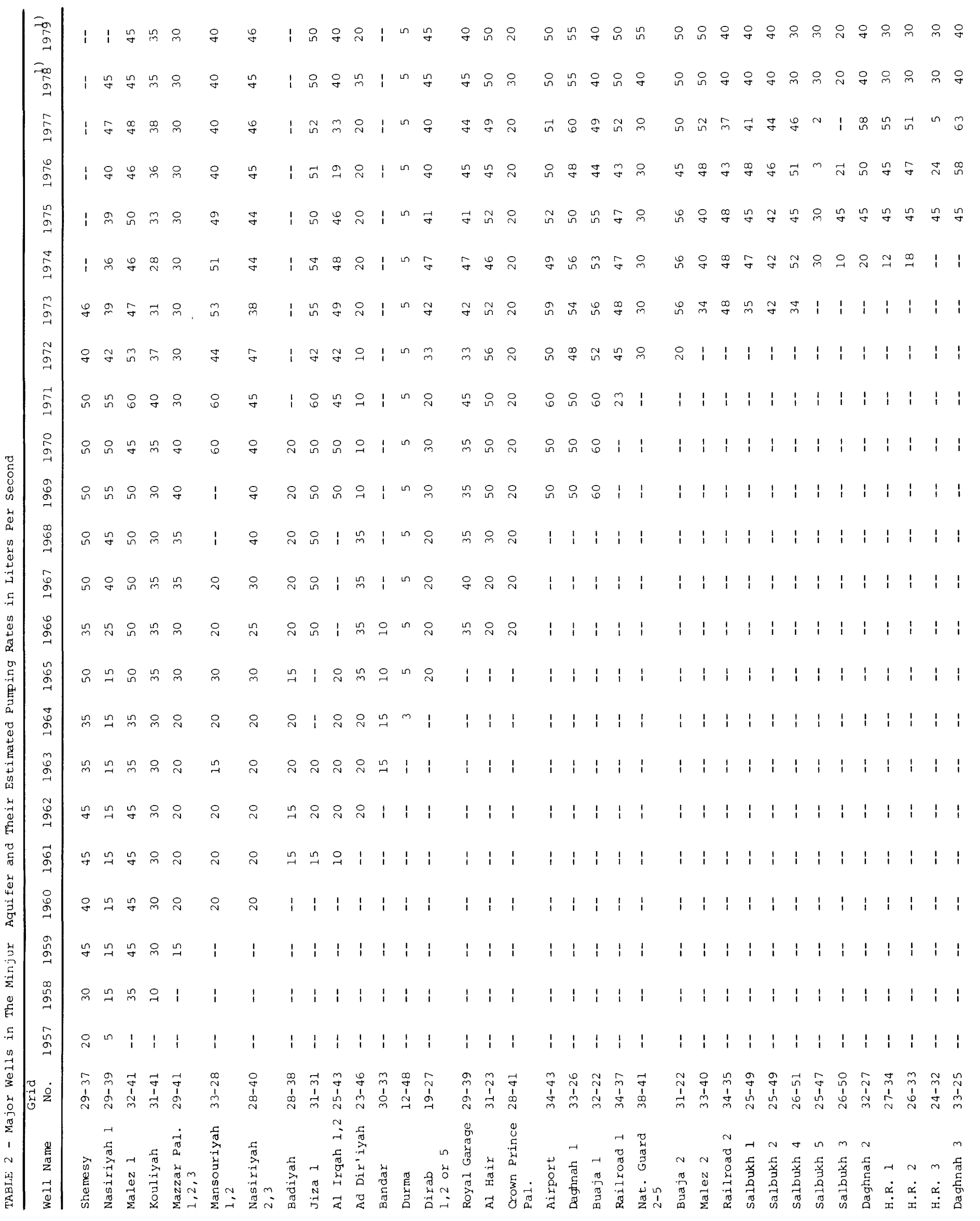




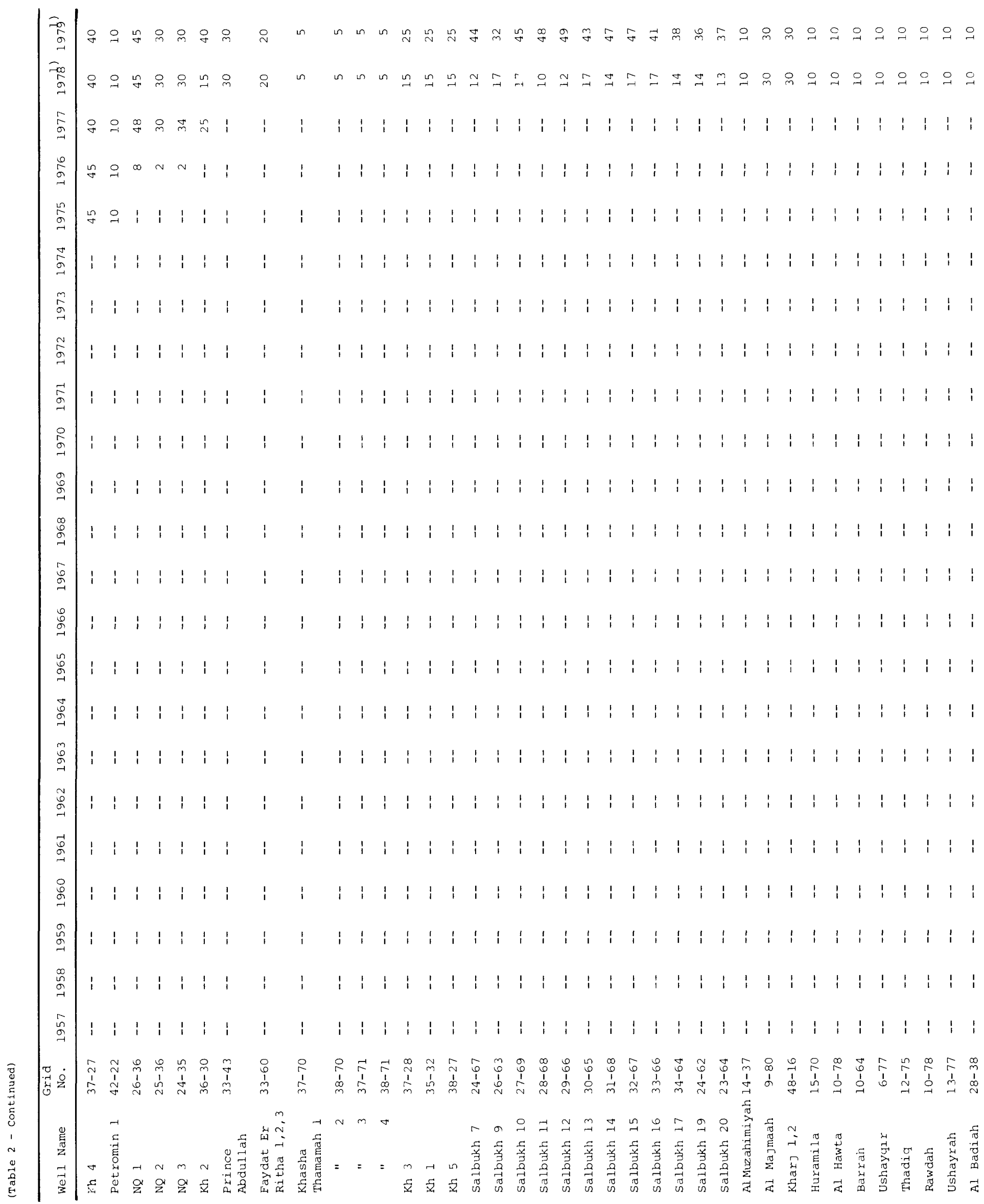

13 


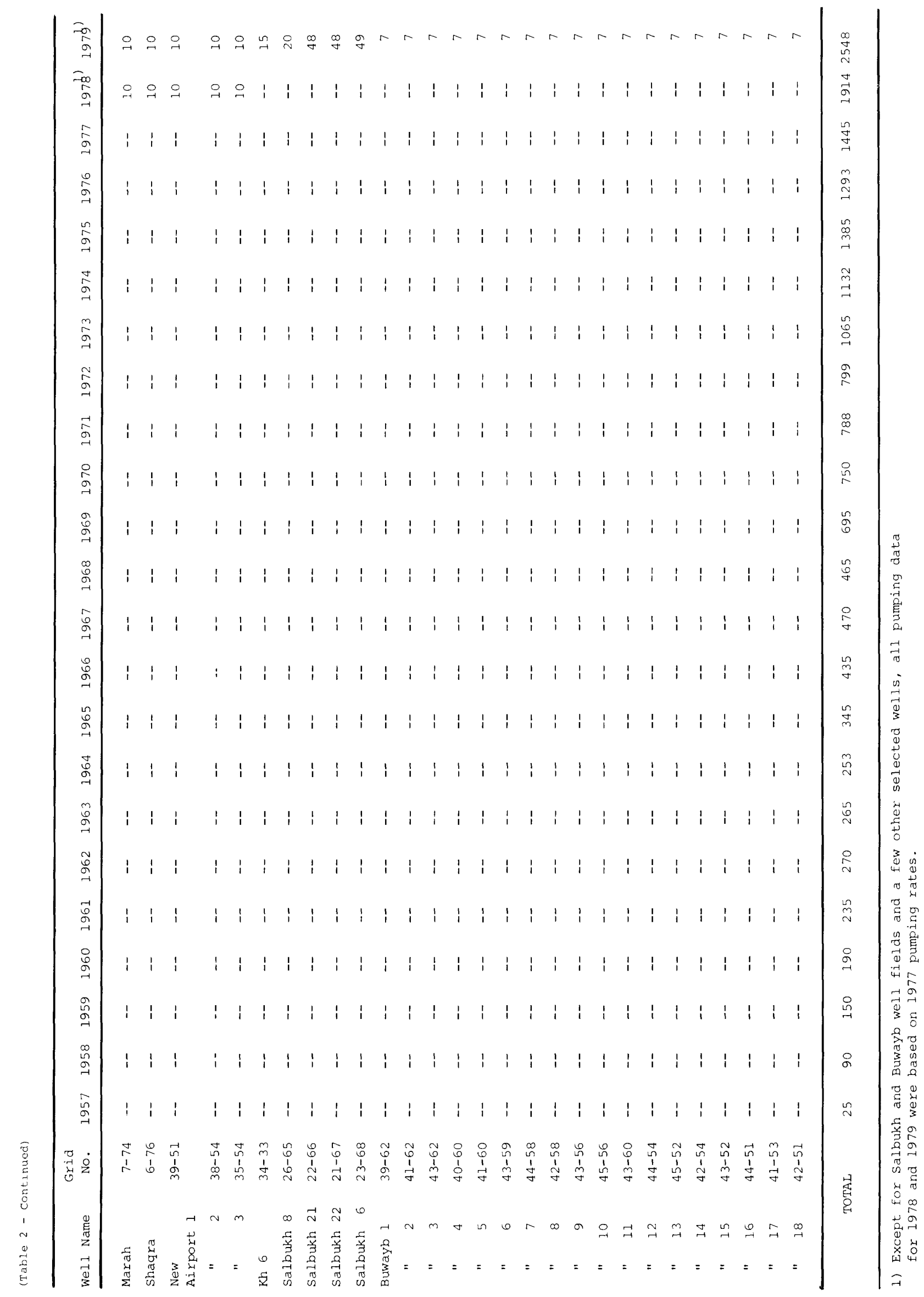




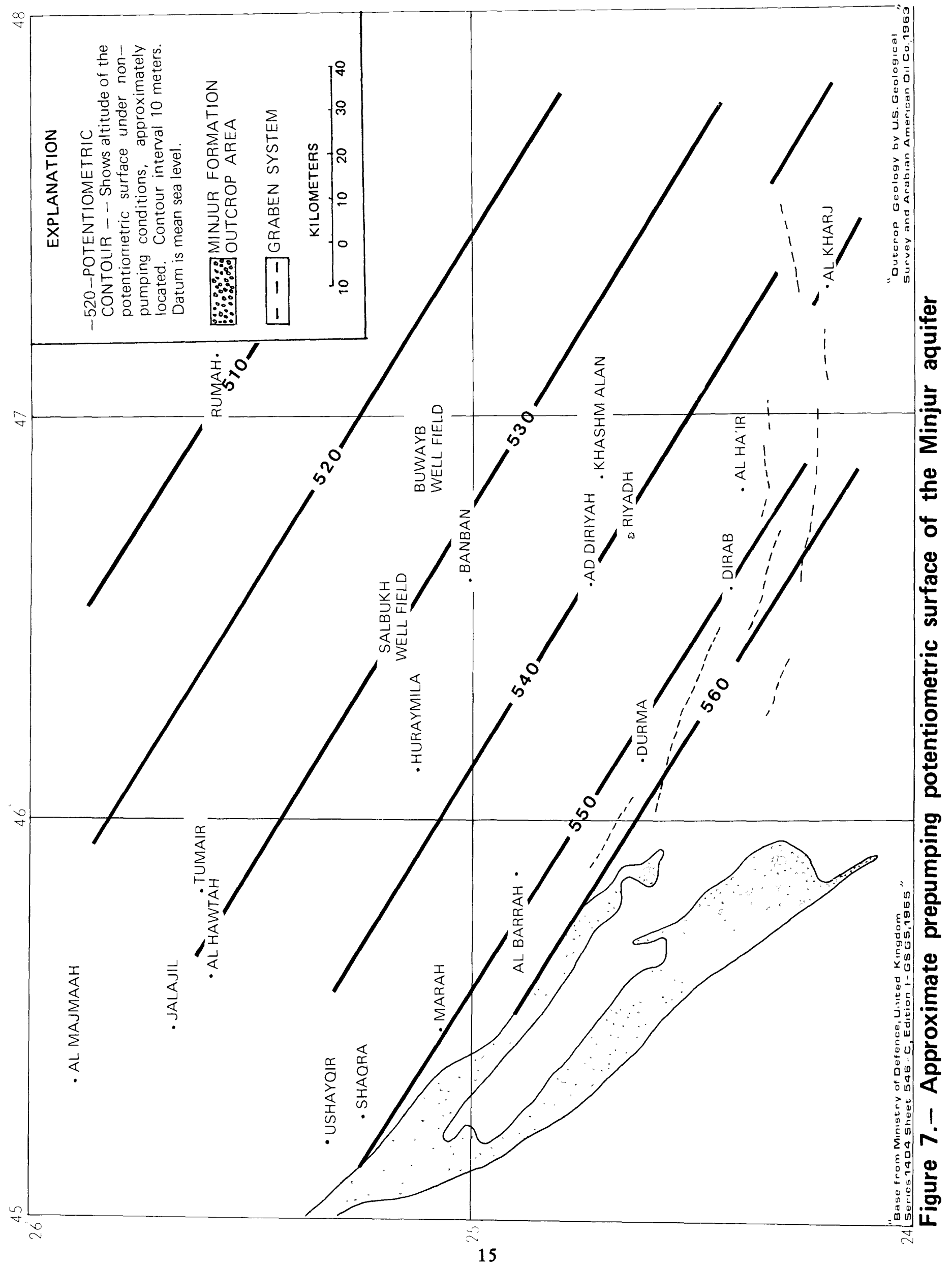




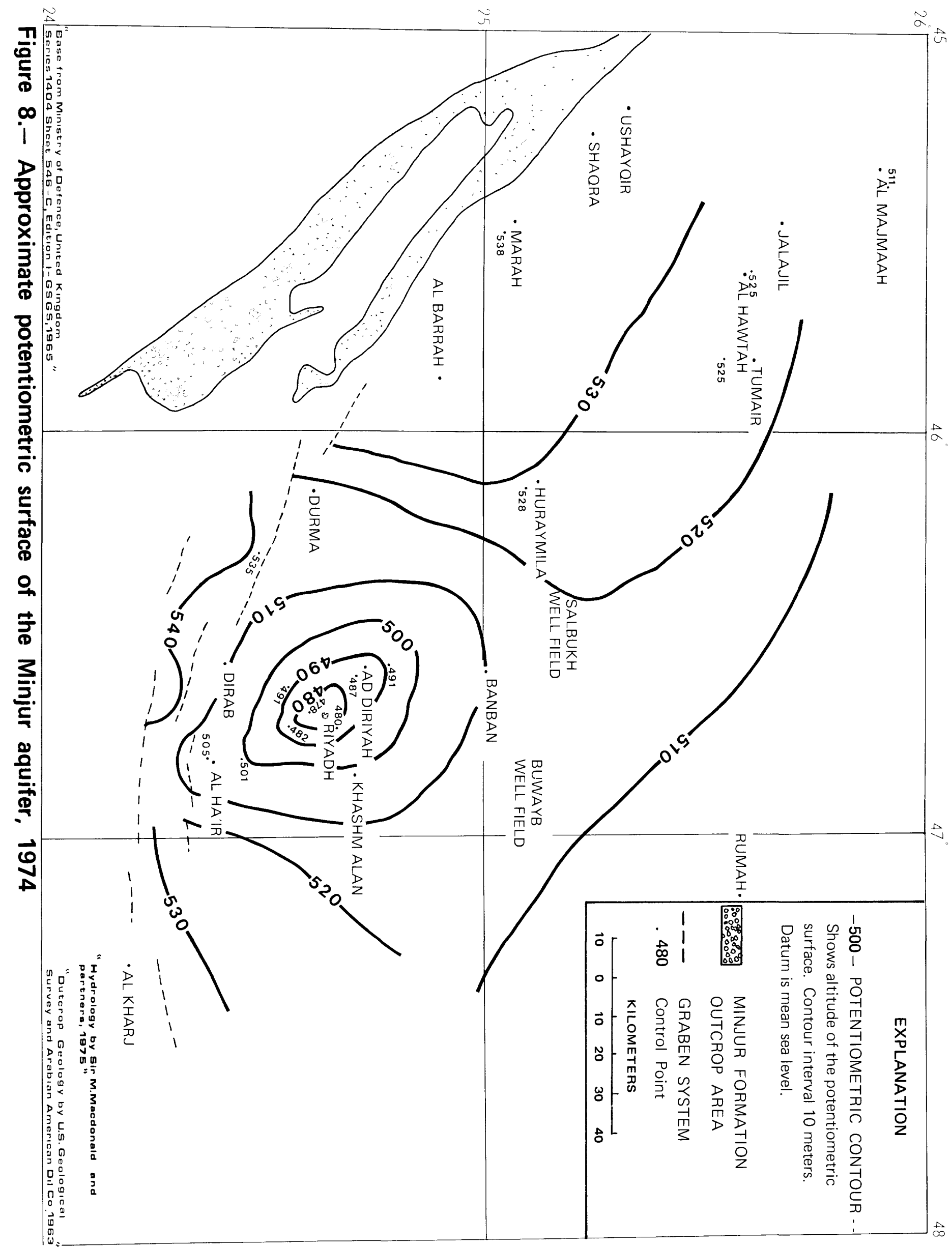


Description of the Minjur Aquifer Model

\section{Grid Design}

The modeled area was divided into a rectangular grid having 62 rows and 84 columns for a total of 5208 blocks or nodes (pl.1). A variable grid was used with the density of blocks being greater where greater density was desired. A multiplication factor of 1.5 was used to vary the block size. The smallest block size is $2.25 \mathrm{~km}^{2}$ and the largest is $292 \mathrm{~km}^{2}$. By convention the point at the center of each block is called the node. The row-column system I, J was used to label each node. For example, the index for the node $(5,9)$ refers to the center of the block which corresponds to row 5, column 9 of the grid. Each input value (transmissivity, vertical conductivity, and so forth) assigned to a node is considered to be the average value over the entire block. Similarly, each output value (hydraulic head, drawdown) is also an average value for that block.

\section{Model Boundaries}

One of the first steps toward the construction of the aquifer model was the selection of boundaries. The model boundaries do not coincide with the boundaries of the study area (fig. 1) because the study area is only a small portion of the entire Minjur aquifer. The Minjur aquifer is present under a large portion of eastern Saudi Arabia. In an east-west direction the Minjur extends from the outcrop area, 100 kilometers west of Riyadh (Pl.1) to some unknown distance and depth east of Khurays. In a north-south direction the Minjur extends from approximately 160 kilometers north of Buraydah to about 150 kilometers southwest of Layla' (fig. 1). The western boundary of the model approximates the actual outcrop of the Minjur and is designated as a no-flow boundary. The northern, eastern, and southern boundaries of the model are also assumed to be no-flow boundaries and were placed far enough away from the study area to have minimal effect on water levels within the study area.

Lower and upper boundaries also are needed for the model. For modeling purposes, vertical leakage was assumed to come only from overlying aquifers because the model program doesn't allow leakage from below. The lower boundary, therefore, was modeled as a no-flow boundary and the upper boundary is defined in the model as a vertical leakage boundary that transmits recharge into the Minjur through overlying confining mate- rials. The rate of vertical leakage depends on the gradient across the confining bed and the vertical conductivity of the confining bed.

\section{Transmissivity and Storage Coefficient}

Average transmissivity values for each block of the grid were estimated from figure 4 and entered into the model as a matrix. Two values were used to represent storage coefficient. In those areas where confined conditions occur, a value of $4 \times 10^{-4}$ was used. In the water table part of the Minjur, 0.07 was used.

\section{Starting Head in the Minjur Aquifer}

Actual steady-state (prepumping) head values were not accurately known, so they could not be used as a starting surface for the Minjur aquifer during model simulations. Therefore, the principle of superposition was utilized; pumpage was treated as a change imposed on an initial condition of no flow (no movement) within the aquifer; drawdown was considered to take place from an initially flat potentiometric surface.

\section{Leakage Factor}

A value for the leakage factor, vertical hydraulic conductivity of the confining bed divided by the thickness of the confining bed, was determined by the trial and error method during calibration of the model. For example, if the model simulation showed that less leakage was required to match the model's simulated water-level changes with the actual measured changes, then the leakage factor was lowered. A vertical hydraulic conductivity of $2 \times 10^{-12} \mathrm{~m} / \mathrm{s}$ best satisfied the above conditions and was used in those areas where the Minjur is confined.

\section{Starting Head in the Recharging Aquifer}

An initial starting potentiometric surface equal to that of the starting surface for the Minjur aquifer was entered for the head of the recharging aquifer. This satisfies the initial boundary conditions of no flow into or out of the Minjur aquifer that are required for use of the superposition technique. The model does not have the capability of varying the head in the contributing aquifer during simulation. 


\section{CALIBRATING THE MODEL}

Computer models are calibrated by having them reproduce past water-level change patterns using known input daita. Once the model is adjusted so that it is able to reproduce the past accurately, it then can be used to predict future results.

The process of calibrating the Minjur aquifer model consisted of varying certain parameters (leakage factor, transmissivity, and to a limited degree, selected pumpages) while at the same time holding other parameters constant (storage coefficient and documented pumpage of major users) and then comparing the model's predicted results with field measurements of water-level changes. Parameters were varied until a reasonable match was obtained.

Several different approaches were considered in the attempt to calibrate the Minjur aquifer model. They included:

(1) entering as starting-head surfaces the prepumping potentiometric maps of the Minjur and the recharging aquifer,

(2) entering as starting-head surfaces the 1974 Minjur potentiometric surface and a 1974 potentiometric surface for the contributing aquifer, and (3) entering the same startinghead surface for both the Minjur and the recharging aquifer.

The many unknowns associated with the prepumping surface and the instability of initial conditions of the 1974 potentiometric surface assure poor calibration by methods 1 and 2 . Consequently, method 3 was selected as the more accurate approach.

In order to simulate the calibration period, pumpage from the aquifer was divided into 23 annual pumping periods, beginning with 1957. The year 1957 was chosen as the initial starting time since pumpage had not taken place in the Minjur aquifer in the Riyadh area before then, and it was, therefore, reasonable to assume that the Minjur was in a steady-state condition. These annual pumping periods and associated rates of pumping are shown on figure 6 . The annual values have been further subdivided into the average withdrawal per well per pumping period (Table 2) and assigned to the appropriate node in the model.

The calibration of the model was checked by comparing the computed water-level changes with measured water-level changes. Table 3 gives the results of the calibration run for 13 observation wells. The location of these wells are shown in figure 5. Table 4 shows the results of the calibration run at the National Guard \# 1 observation well which has the longest continuous record of any well in the Minjur aquifer. In general, the agree- ment was good between the computed and the measured water-level changes. Further refinement was believed to be unwarranted because of the uncertainties in some of the field data.

\section{Future Water Level Changes}

After the model was calibrated, it was used to predict future water-level declines. For example, if the model was simulated for the 2 year period, 1980-81, the results of the model will show only the amount of water-level decline occurring from 1980 through 1981. Several different schemes were simulated in order to test the effects new pumping rates would have on the future water levels in the Minjur aquifer. The simulations consisted of the following:

1. Pumpage Plan 1-A series of simulations using the best estimate of future pumpage for the following periods:
a) $1980-81$
b) $1980-89$
c) $1980-1999$
d) 1982-1999

2. Pumpage Plan $2-$ A predictive simulation using the best estimates of future pumpage for all wells except those in the Buwayb well field for the period 1980-1999. In this case, the Buwayb well field was simulated at its theoretical capacity.

3. A simulation showing the predicted additional drawdown in selected pumping wells in the Buwayb well field (short term analysis).

4. A simulation showing the predicted additional drawdown in the pumping wells in the Buwayb well field if all Buwayb wells are pumped (long term analysis).

There are no new well fields planned for the Minjur aquifer in the Riyadh area. A few additional wells, however, are presently in various stages of completion and are scheduled to begin production in 1982. The location of these new wells is shown on Figure 5. The 1980-81 predictive simulation essentially utilizes the same withdrawal nodes as those used for the model calibration. Beginning in 1982, however, the model incorporates the additional pumpage from the new wells.

Pumpage Plan 1 - Projected water-level declines based on best estimates of future withdrawals.

A series of transient predictions was simulated using best estimates of future withdrawals. Figure 9 shows the estimated future Minjur pumpage rates. These estimates were determined by assuming that 


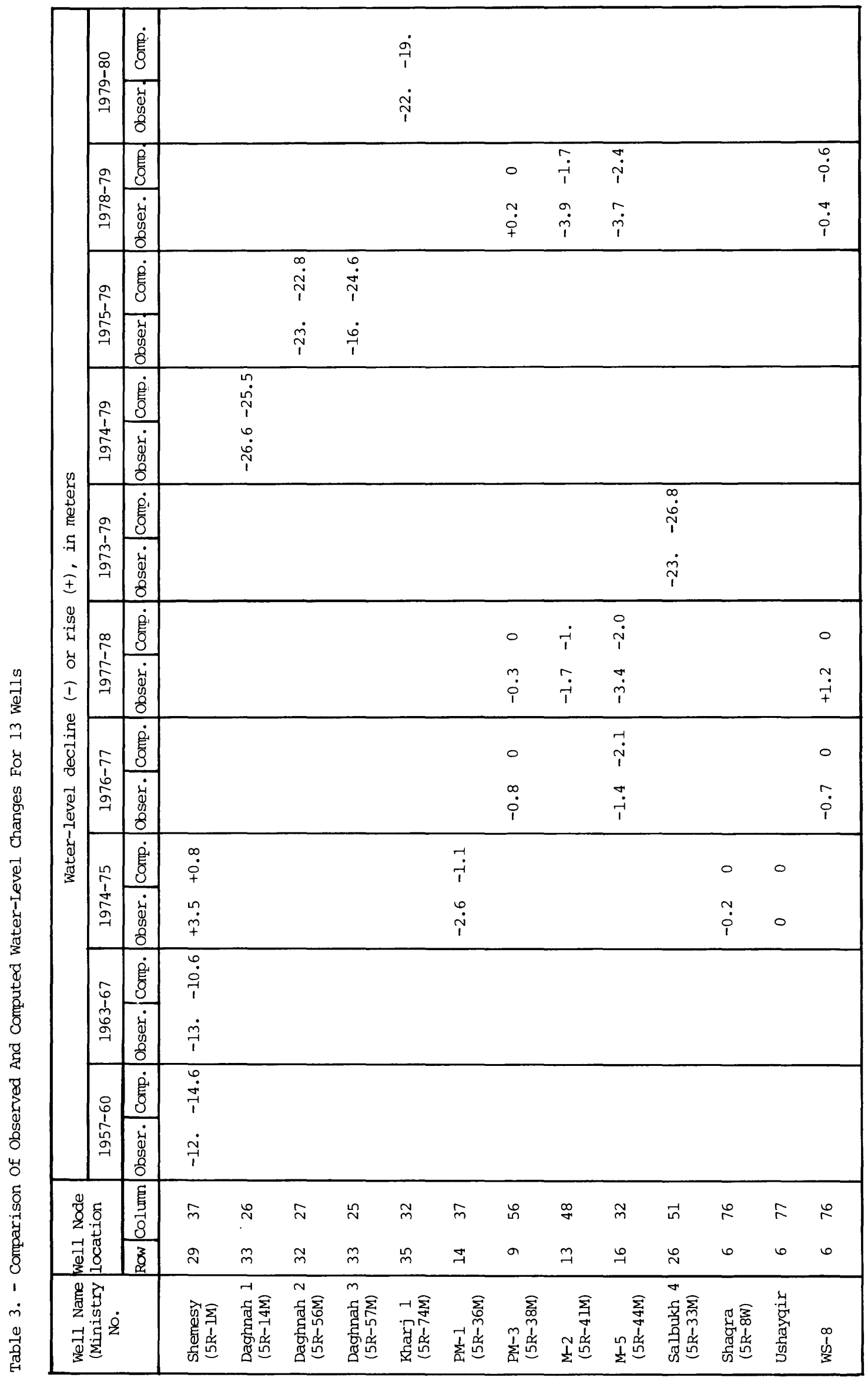


Table 4. - Comparison Of Observed And Computed Water-Level Changes at National Guard Well \#l (Node 35-33)

\begin{tabular}{|c|c|c|}
\hline \multirow[b]{2}{*}{ Date } & \multicolumn{2}{|c|}{ Water-level change, in meters } \\
\hline & Observed & Computed \\
\hline Oct. 1962 - Dec. 1966 & -13.83 & -9.2 \\
\hline Dec. 1966 - Dec. 1967 & 0 & $-\quad 2.4$ \\
\hline Dec. 1967 - Jan. 1970 & -5.98 & -6.0 \\
\hline Jan. 1970 - Dec. 1970 & -7.56 & -5.6 \\
\hline Dec. 1970 - May 1971 & -2.10 & -4.7 \\
\hline May 1971 - Mar. 1972 & -2.74 & -1.4 \\
\hline Mar. 1972 - Dec. 1973 & -9.69 & -8.5 \\
\hline Dec. 1973 - Dec. 1974 & -4.2 & -3.8 \\
\hline Dec. 1974 - Dec. 1977 & -19.8 & -17.1 \\
\hline Dec. 1977 - Dec. 1979 & -10.0 & -14.1 \\
\hline Oct. 1962 - Dec. 1979 & -75.9 & -72.8 \\
\hline
\end{tabular}


all existing wells except those in the Buwayb well field would continue to be pumped at their 1979 pumping rate (Table 2). Further, it was assumed that each well in the new Buwayb well field would produce a yearly average of $401 / \mathrm{s}$. Beginning in 1982, the additional Minjur wells which are scheduled to begin production in that year are incorporated into the future withdrawals. All of the water level declines obtained in this particular simulation represent regional effect, such as would be observed in a non-pumped observation well. The model in this section of the report does not simulate the local drawdown around or within individual pumping wells (Drawdown in selected individual pumping wells is discussed beginning on page 21 of this report).

Figure 10 shows the water-level decline in a non-pumped observation well predicted to occur from 1980 through 1981 as a result of estimated future pumping (fig. 9). Water levels around Riyadh will drop about 8 meters from 1980 through 1981. The Salbukh well field will experience declines from 18 to 30 meters while waterlevels in the Buwayb well field will decline from 30 to 60 meters.

Figure 11 shows the predicted water-level declines from 1980 through 1989 based on the best estimates of future pumping (fig. 9). Water levels in the Minjur aquifer in the city of Riyadh should have declines of about 35 meters from 1980 through 1989 . The well field areas to the north of Riyadh, Salbukh and Buwayb, will undergo water-level declines of 40 to 75 meters from 1980 through 1989.

Figure 12 shows the results of a simulation for the period 1980 through 1999. By the year 2000, water levels should be about 37 meters lower in Riyadh than they were in 1980 . The Salbukh and Buwayb fields should have declines of 45 to 90 meters. In the Riyadh, Salbukh and Buwayb areas, the absolute amounts of water-level decline from 1980 through 1989, and from 1980 through 1999 are quite similar, there being only a few additional meters of decline after 1990 . The reason for this is that the cone of water-level decline has now spread outward in all directions and, consequently, there is a greater area over which water-levels are decreasing.

Figure 13 shows the water-level declines predicted to occur from 1982 through 1999. This simulation is included in order to demonstrate that a large portion of the water-level decline from 1980 through 1999 in the Buwayb-SalbukhRiyadh area will take place from 1980 to 1982 . The Buwayb well field illustrates this quite well. From 1980 through 1981, water-levels in the Buwayb well field are predicted to decline by 30 to 60 meters (fig. 10). During 1982-1999 the average water-level decline for the entire well field is predicted to be about an additional 32 meters (fig. 13). Water-levels will decline as much or more during the first two years of production as they will during the next 18 years.

Pumpage Plan 2- Predicted water-level declines based on best estimates of future withdrawals plus theoretical maximum pumpage from the Buwayb Well Field.

The pumping criteria for this simulation is essentially the same as for Pumpage Plan 1. In this case, however, all wells in the Buwayb well field are producing at their maximum possible rate of $58 \mathrm{1} / \mathrm{s}$. Figure 14 shows the results of this simulation for the period 1980-1999. In essence, this prediction shows the upper limit of declines in the water-level in the Minjur aquifer from 1980 through 1999. Under this set of criteria, it is unlikely that water levels will decline more than shown on Figure 14 for the period 1980-1999. This is a worst case prediction and therefore, extremely valuable for long-term planning. Under this simulation, water-levels in the Minjur at Riyadh will decline about 42 meters. The Salbukh well field area should have water-level declines from 50 to 80 meters; the Buwayb well field area should have water-level declines from 55 to slightly less than 120 meters.

\section{Simulated Additional Pumping Level Decline in Wells in the Buwayb Well Field}

\section{Short Term Analysis}

Table 5 shows the simulated drawdown of pumping levels in selected wells in the Buwayb well field from January through May, 1980 and January through October 1980. The pumpage scheme of this simulation is essentially the same as Pumpage Plan 2 (p.21) except for the number of producing wells in the Buwayb field. It was estimated that the amount of water required from the Buwayb field during the winter and spring months (January-May) can be met by utilizing 6 wells at their full production capacity. From June through October it was estimated that full production of 14 wells could satisfy water requirements (Eugene Risch, Project Execution Department, Ministry of Agriculture and Water, Riyadh, Saudi Arabia, oral commun., 1979). This prediction, therefore, simulates the full production capability $(581 / \mathrm{s}$ per well) of 6 Buwayb wells from January through May 1980 and increases the number of full production wells to 14 from June through October 1980. 

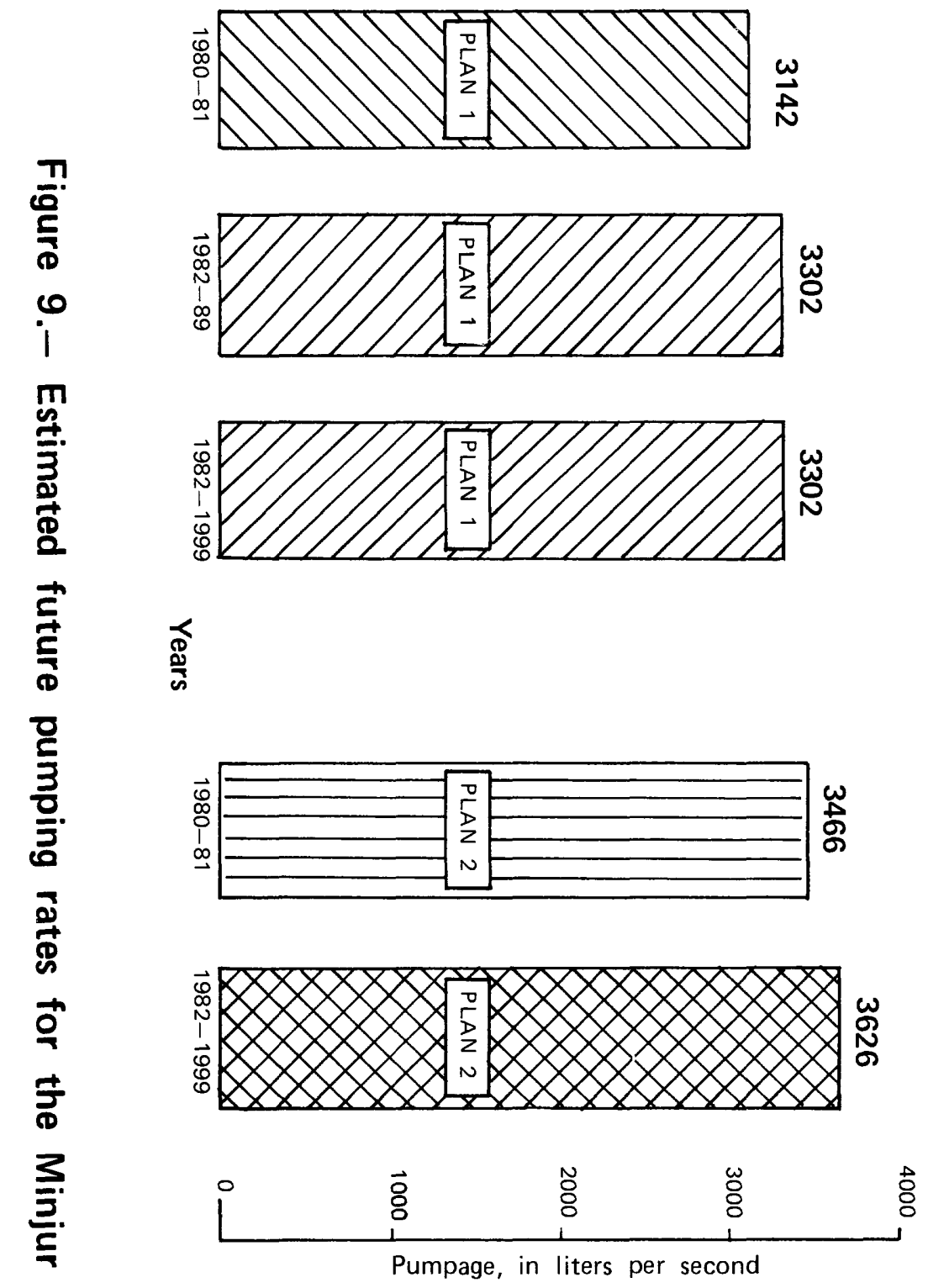

焕

용

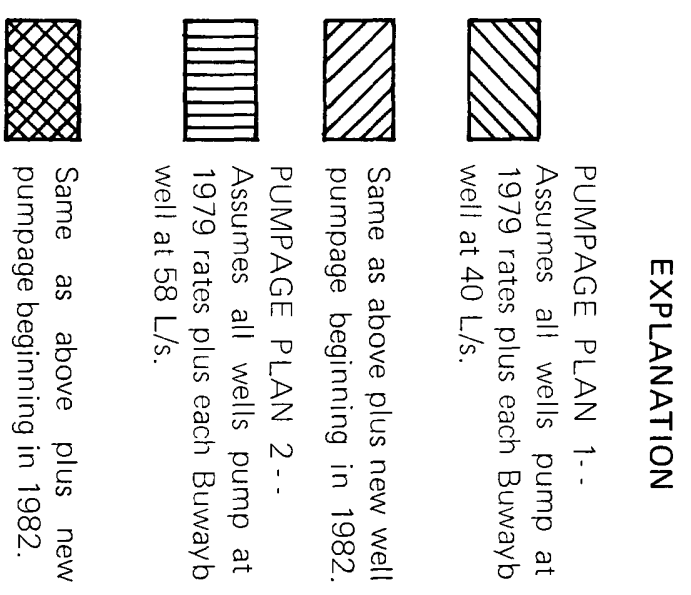




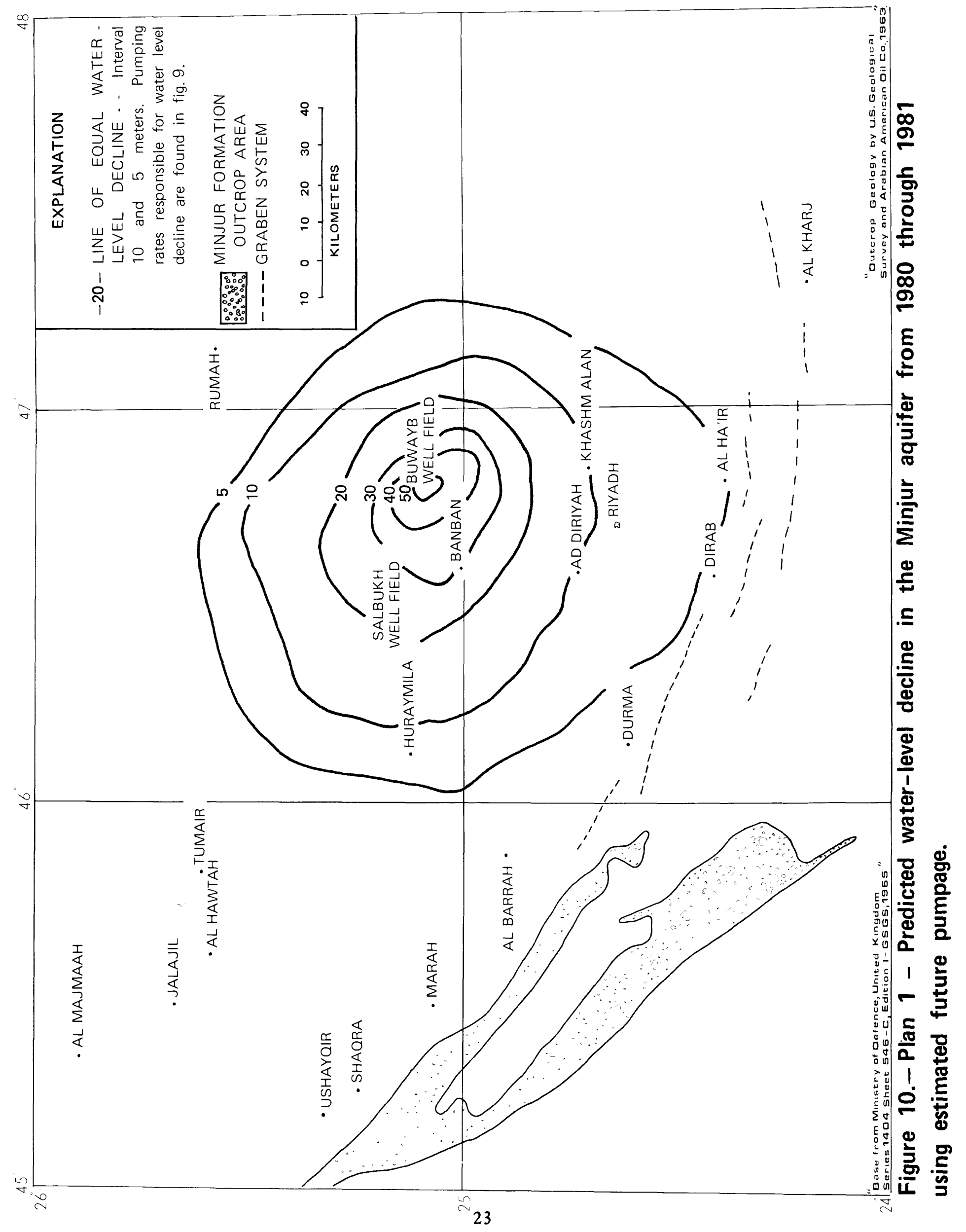




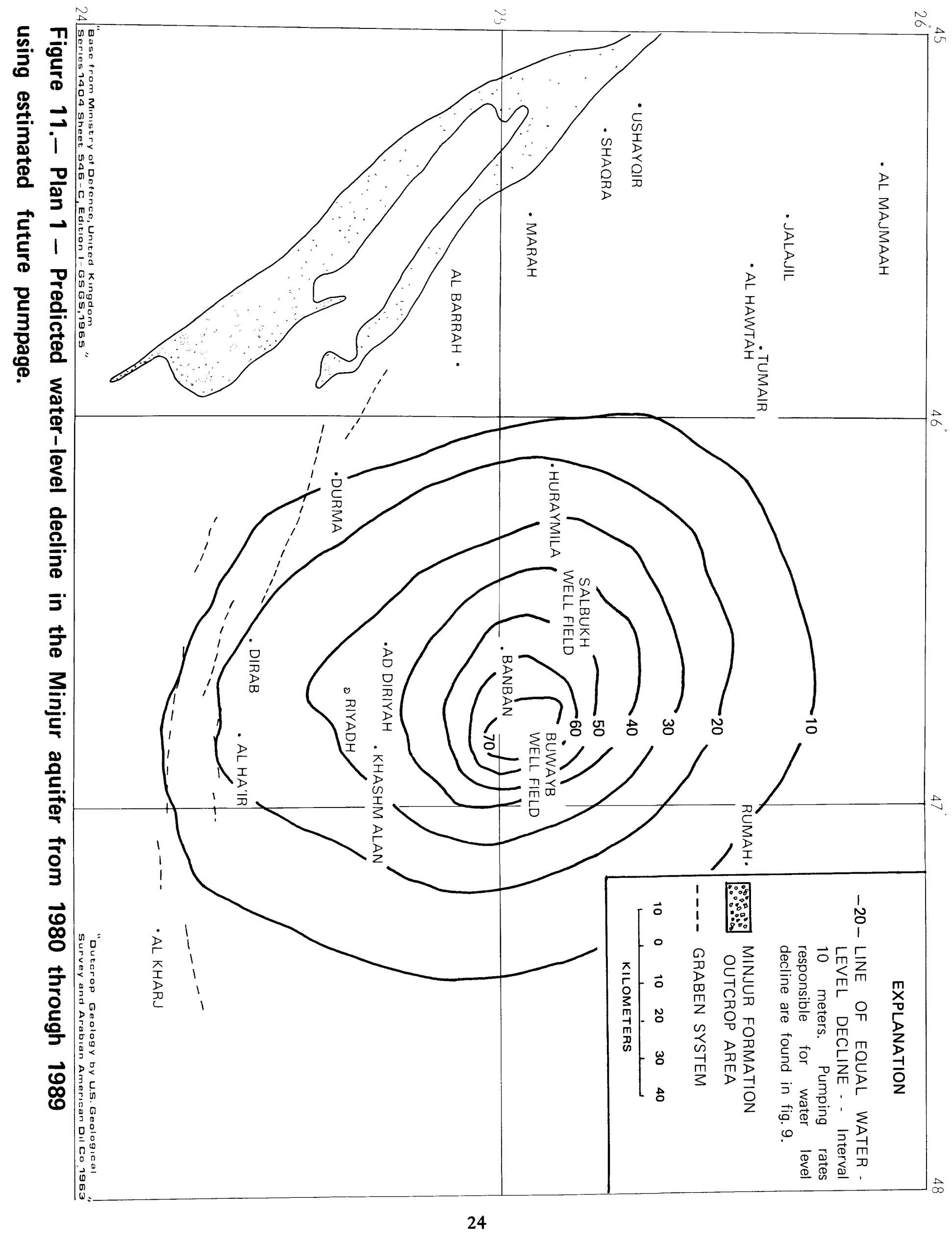




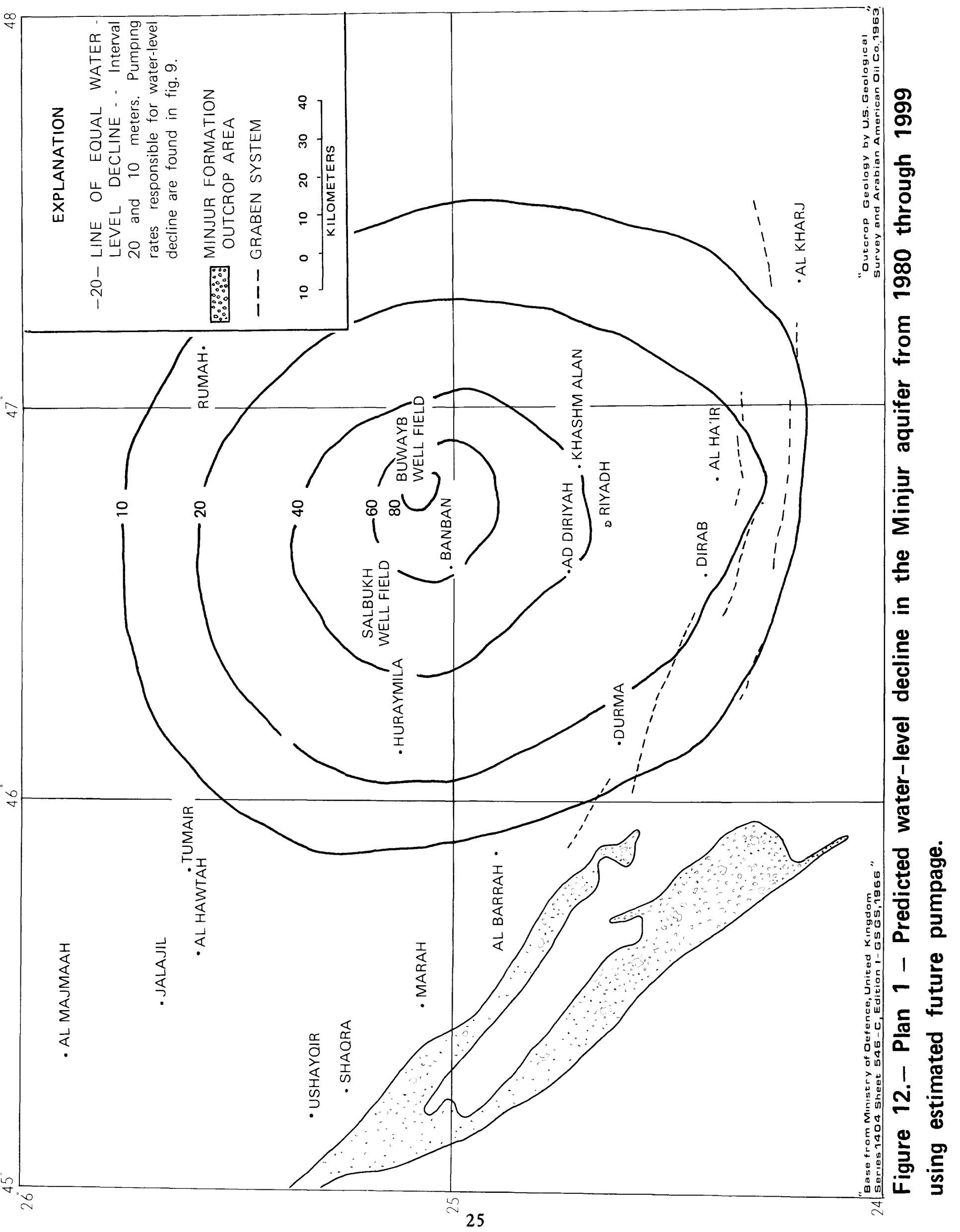




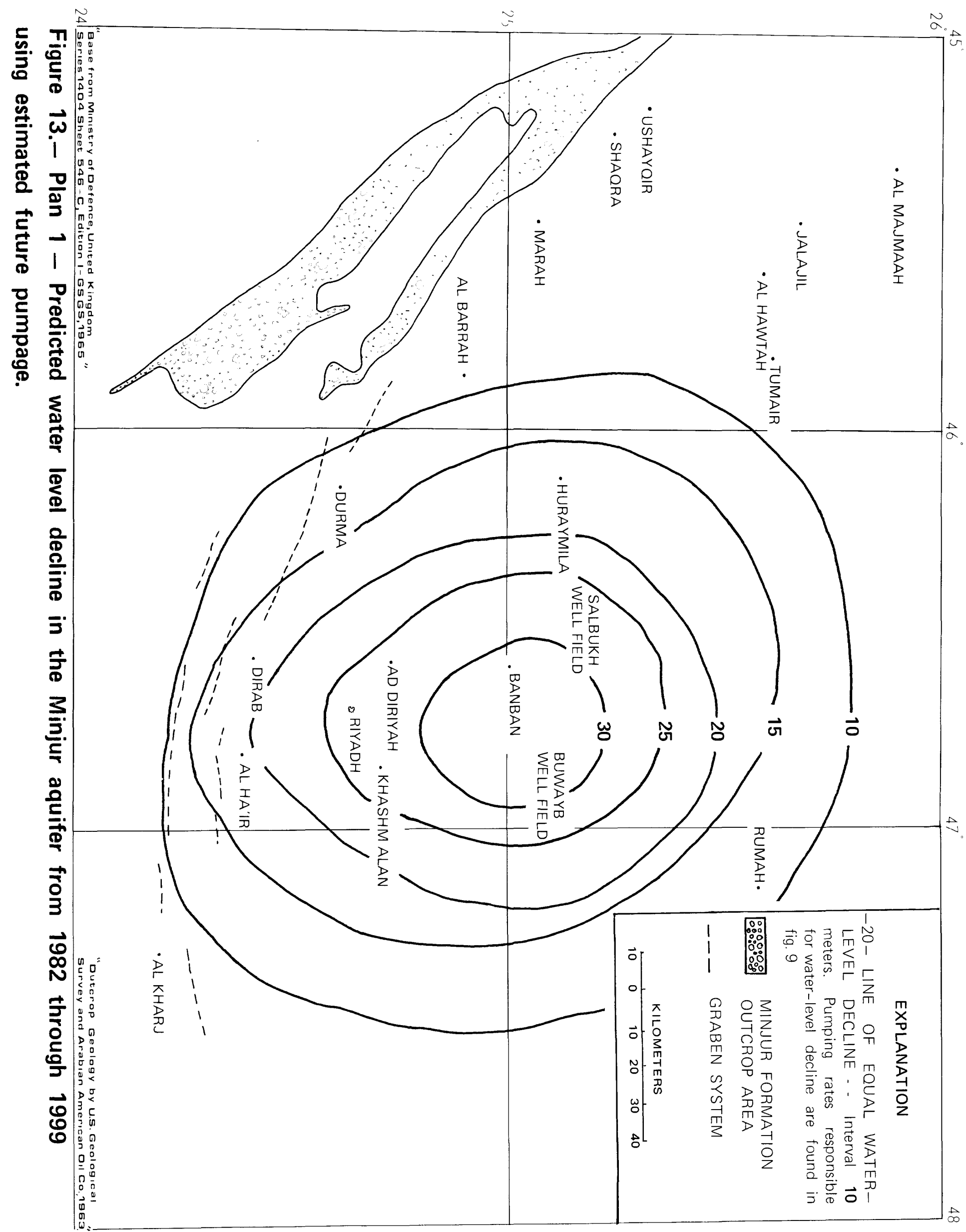




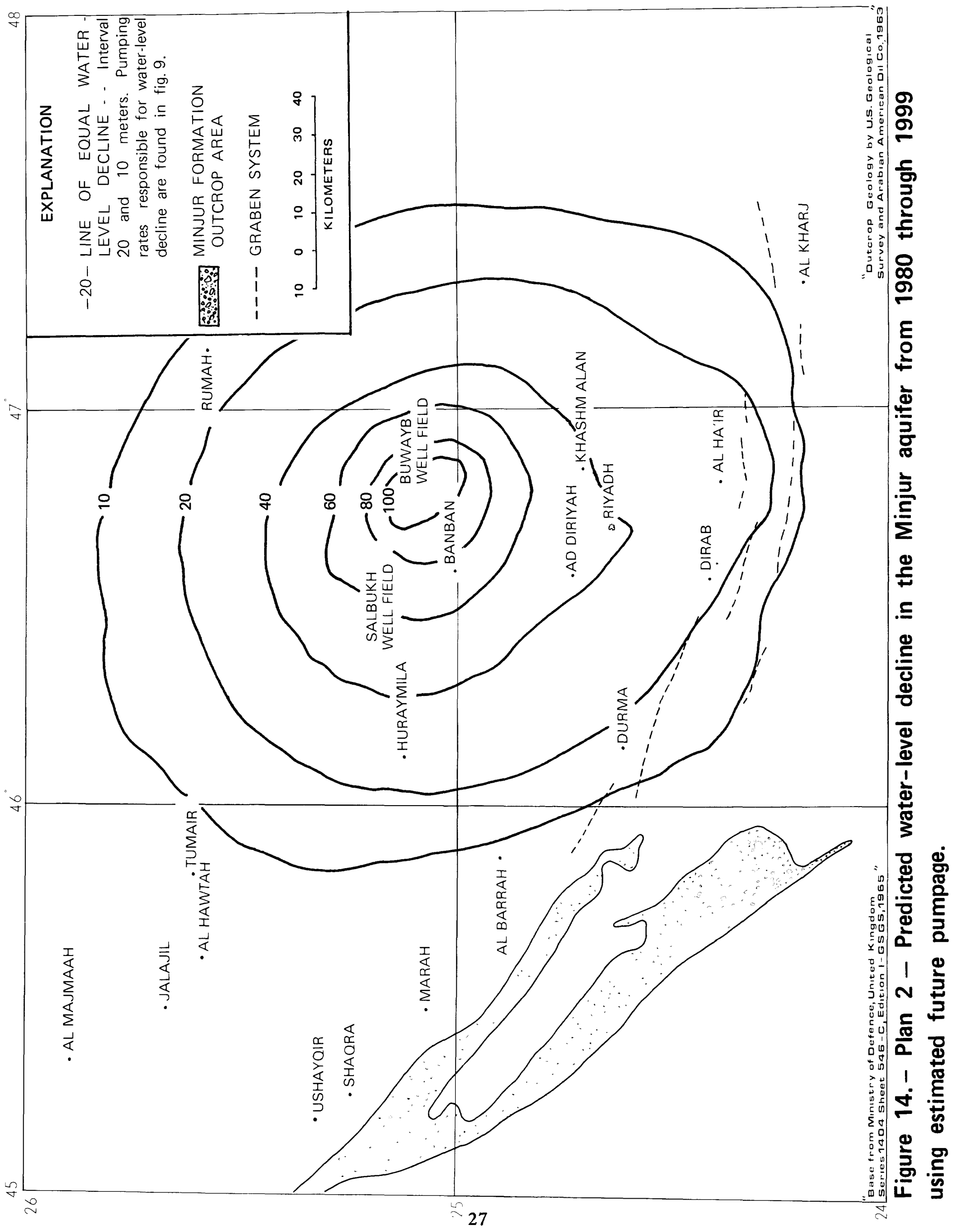


Table 5 shows that from January through May 1980 , the pumping levels in selected wells in the Buwayb field should have declined 34 to 36 meters with a 100 percent well efficiency and 49 to 51 meters with a 70 percent well efficiency. From January through October 1980 , the pumping wells should have declines in pumping levels of 48 to 59 meters with a 100 percent well efficiency and of 69 to 84 meters with a 70 percent efficiency.

Although well efficiency does not have an effect on regional water levels in an aquifer (not applicable to fig. $10-14$ ), it does affect the dynamic (pumping) levels in the well. The efficiency of a well can be defined as the ratio of the amount of drawdown that should have occurred in a well to that of the actual drawdown in the well - under a constant pumping rate. The efficiency of wells in the Minjur aquifer generally varies between 50 and 90 percent. Seventy percent, therefore, was taken as the average well efficiency.

As the water-level declines computed in the model for each node represents an average waterlevel change for the entire node and is not usually the water-level change in the well itself, an additional computation must be used when water-level changes in the well are sought. A procedure by Prickett (Trescott and others, 1976, p. 9-10) that will calculate the pumping level change estimates in the well itself was used for this simulation. A condition of this procedure requires that only one well be included in a node. This simulation satisfies that condition as each well in the Buwayb well field is assigned to a separate node.

\section{Long Term Analysis}

Table 6 shows the predicted additional pumping level decline in each well of the Buwayb well field from 1980 through 1981 and from 1980 through 1989 if every well within the field (18 wells) produces a yearly average of $401 / \mathrm{s}$. During 1980-81 additional drawdowns of 77 to 96 meters are predicted to occur with a 70 percent well efficiency. Between 1980-89 additional drawdowns of 114 to 136 meters are predicted to occur with a 70 percent well efficiency.

This simulation as with the previous simulation also uses Prickett's method (Trescott and others, 1976, p. 9-10) to compute water-level declines in the well. 


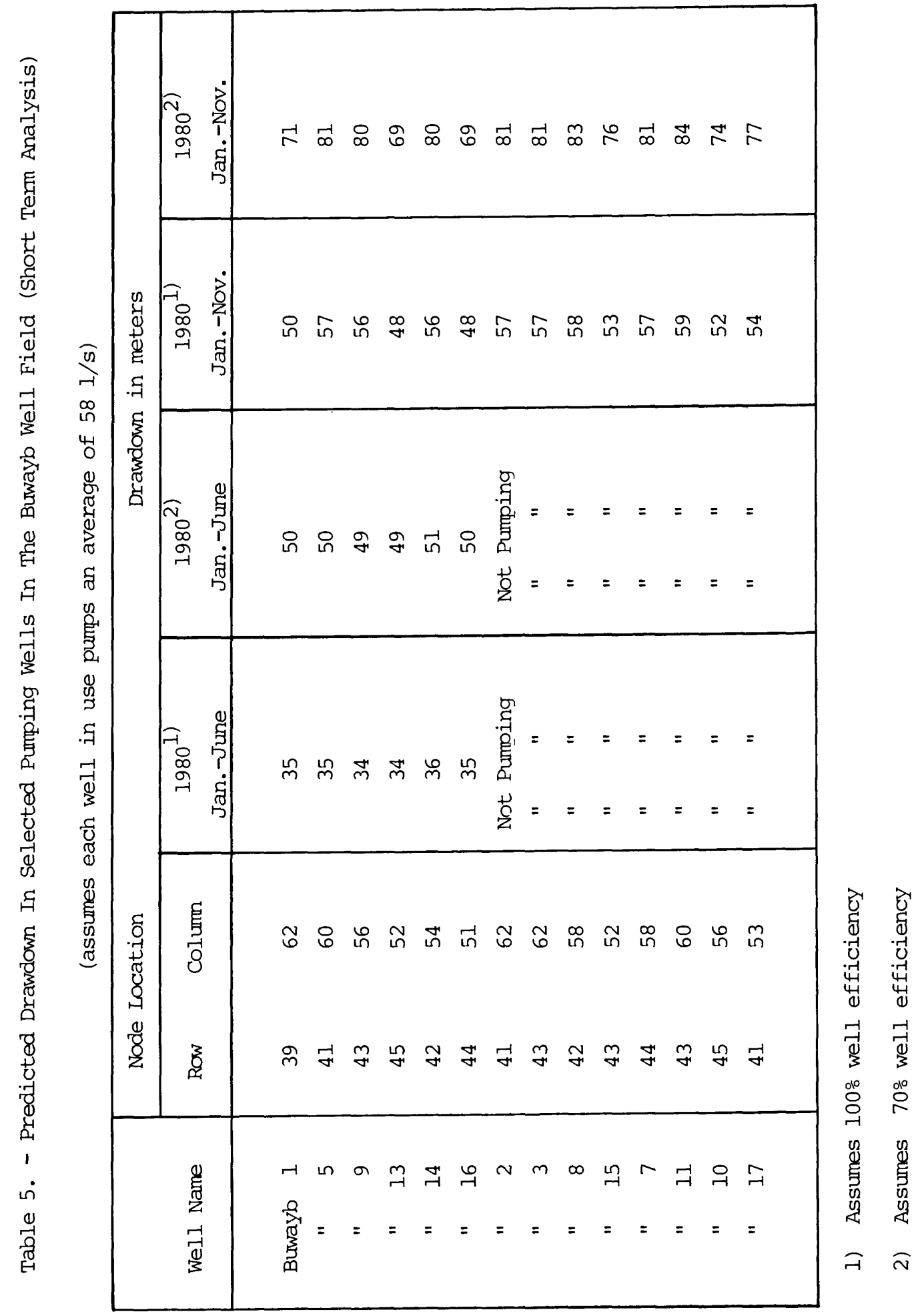




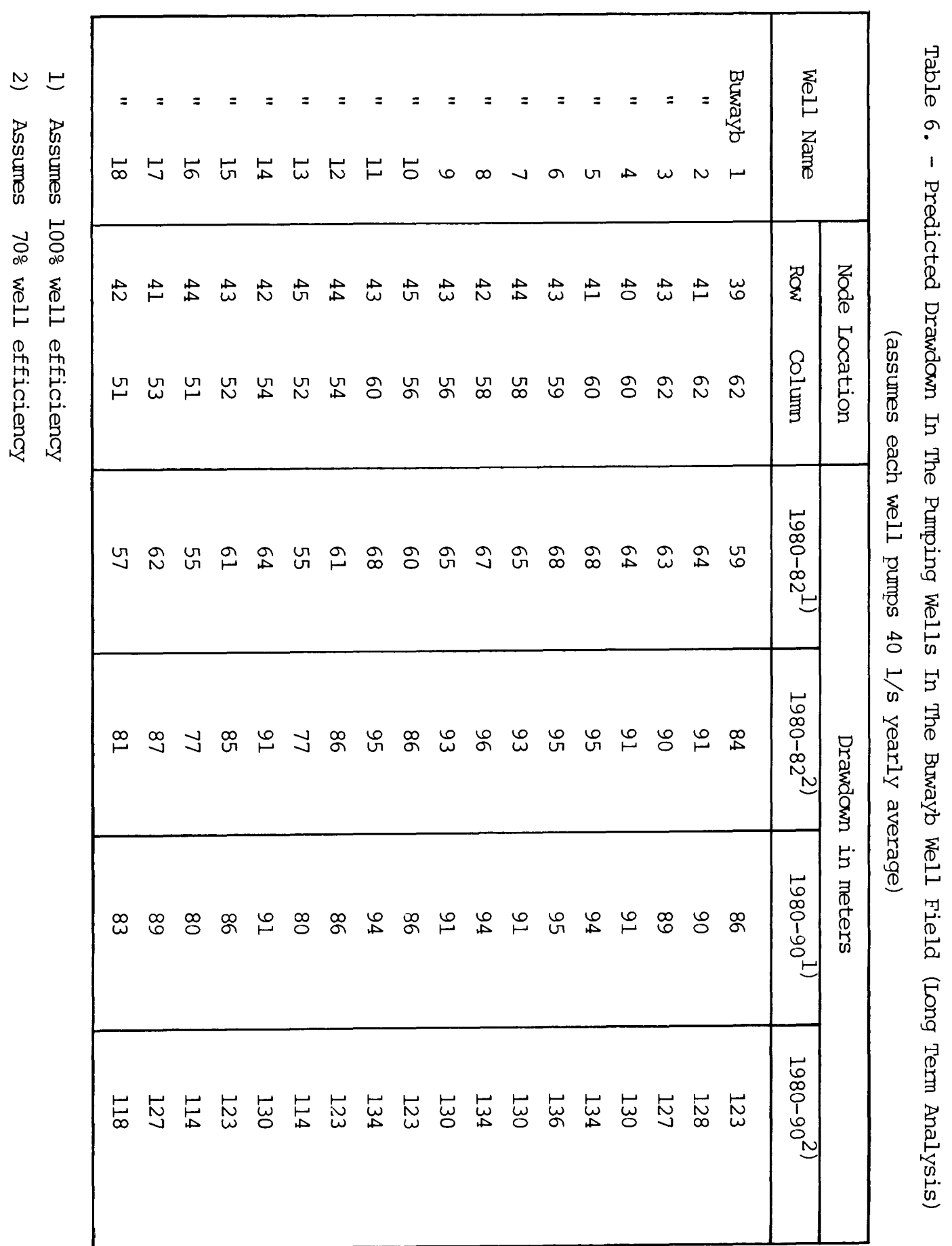




\section{CONCLUSIONS}

A two-dimensional finite-difference digital computer model of the Minjur aquifer was developed to simulate future water-level declines in the aquifer resulting from selected pumping arrangements. This model should not be considered as "the final Minjur model", as it is substantiated only in places. It is useful, however, for many types of planning purposes. Additional revision and testing of the model should be undertaken as more data become available.

Calibration of the model was achieved by comparing computed and measured water-level changes at 14 observation wells for various time periods from 1957 through 1979. The model's first pumping period began in the year 1957 when steady-state conditions existed. Pumpage used in the simulation increased from $251 / \mathrm{s}$ for the 1957 time period to $2548 \mathrm{1} / \mathrm{s}$ for the 1979 period.

Predictive simulations indicate that if the Minjur were stressed by the best estimates of future withdrawals for all simulated wells (pumpage plan 1), substantial water-level declines will occur in certain locations. For the 1980-1999 simulation, the model predicted static water-level declines of about 37 meters in Riyadh; from 45 to 65 meters in the Salbukh well field area; and from 50 to 90 meters in the Buwayb well field area. If the Minjur aquifer were stressed by the best estimates of future withdrawals for all wells except the Buwayb field, and the Buwayb field is stressed at its theoretical capacity (58 1/s per well), then the potential maximum water-level decline for the 1980-1999 period would range from 55 to slightly less than 120 meters at the Buwayb well field area; from 50 to 85 meters at the Salbukh well field area; and about 42 meters in Riyadh.

Predictive simulations also indicate that large water-level declines ( 77 to 96 meters, assuming a 70 percent well efficiency) in the pumping in the Buwayb well field are predicted from 1980 through 1981. The assumption being that each well in the Buwayb field has an average yearly pumping rate of $401 / \mathrm{s}$.

The lack of historical pumpage and water-level data weakened the calibration process. To obtain a good confirmation of the model throughout the study area, it would be necessary to have historical water-level data from a network of strategically placed observation wells. Because pumping data were rarely recorded accurately before 1980, many of the older pumping rates used in the model were best-guess estimates. 
Brown, Glen F., and Lough, Charles F., 1963, Water Supply for Riyadh, Saudi Arabia: U.S. Geological Survey Open-file report, 41 p.

Khatib, Abdel Basset, 1974, Seven Green Spikes: Ministry of Agriculture and Water, Kingdom of Saudi Arabia, 226p.

Kruseman, G.P., 2nd and deRidder, N.A., 1970, Analysis and evaluation of pumping test data: International Institute for Land Reclamation and Improvement Bulletin 11, $200 \mathrm{p}$.

Lohman, S.W., and others, 1972, Definitions of selected ground-water terms - revisions and conceptual refinements: U.S. Geological Survey Water-Supply Paper 1978, 21 p.

Papadopulos, Stravros S., and others, 1977, Alternative sources for additional water supply for Riyadh, Saudi Arabia: United StatesSaudi Arabian Joint Commission on Economic Cooperation, 110p.

Pinder, G.F., 1969, An iterative digital model for aquifer evaluation: U.S. Geol. Survey openfile report, $43 \mathrm{p}$.

Pinder, G.F., and Bredehoeft, J.D., 1968, Application of the digital computer for aquifer evaluation: Water Resources Research, v.4, mo. 5, p.1069-1093.

Powers, R.W., Ramirez, L.F., Redmond, C.D., and Elberg, E.L. Jr., 1966, Geology of the Arabian Peninsula: U.S. Geological Survey Professional Paper 560-D, 147p.
Quimpo, Jesus S., 1972, Preliminary report Water-levels in Minjur at Riyadh, Ministry of Agriculture and Water, report No. 389/106/ 9211, Kingdom of Saudi Arabia, 8p.

Remson, Irwin, Hornberger, G.M., and Molz, F.J., 1971, Numerical methods in subsurface hydrology: New York, Wiley-Interscience, $389 \mathrm{p}$.

Sir M. MacDonald and Partners, 1975, Riyadh additional water resources study: Ministry of Agriculture and Water, Kingdom of Saudi Arabia.

Sogreah, 1968, Area V - Final Report: Ministry of Agriculture and Water, Kingdom of Saudi Arabia.

Trescott, P.C., Pinder, G.F., and Larson, S.P., 1976, Finite-difference model for aquifer simulation in two dimensions with results of numerical experiments: U.S. Geol. Survey Tech. Water Resources Env., book 7, chap. C1, 116p.

Vattenggnadsbyran, June, 1976, Master plan for Riyadh water distribution system: Riyadh Water Treatment and Distribution System.

Walton, W.C., 1970, Groundwater resources evaluation: New York, McGraw-Hill, Inc., $664 p$. 


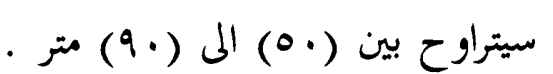
واذا قدر لطبقة المنجور المائية حسب المبن المسن التقدير المبرات

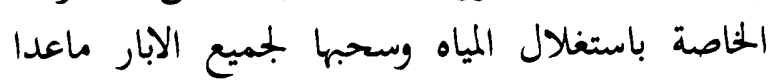

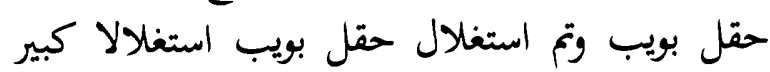

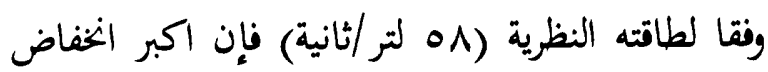

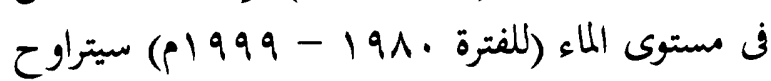

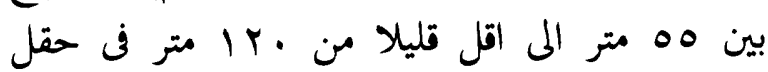

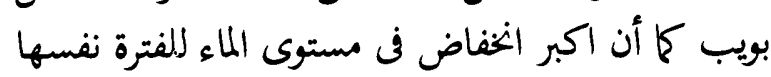

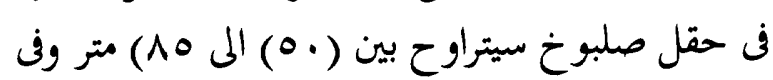

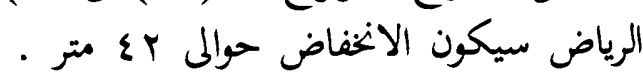

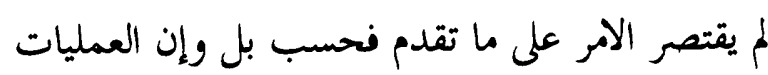

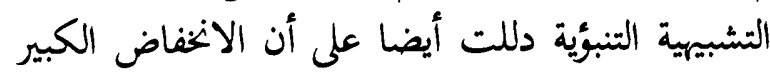
97 - VV)

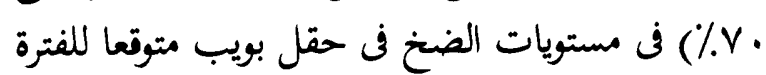

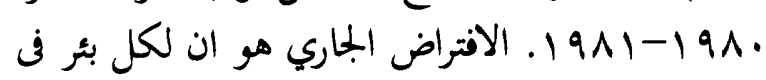

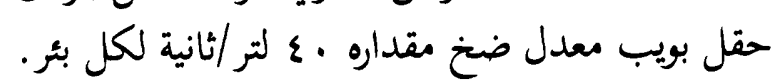

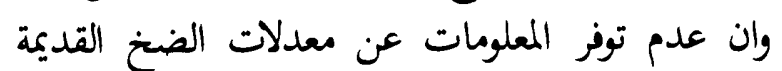

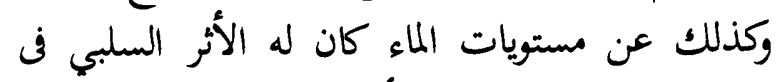

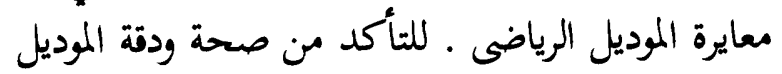

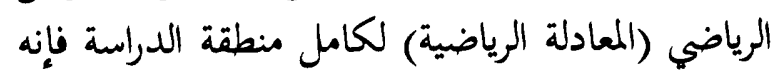

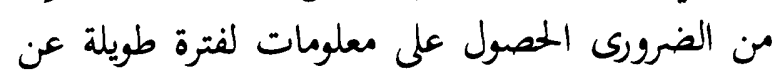

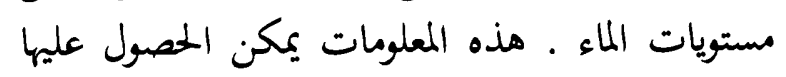
عن طريق توفر شبكة من ابار مراقبة موزعة توزيعا

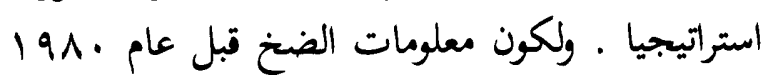

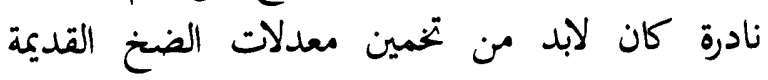

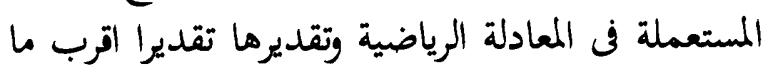

يكون للصحيح المستمل في المعادة
لقد تم اعداد موديل رياضى (معادلة رياضية) ذو اتجاهين

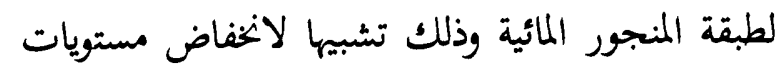

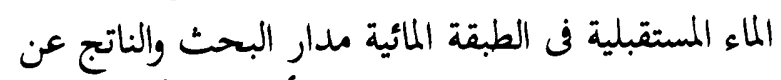

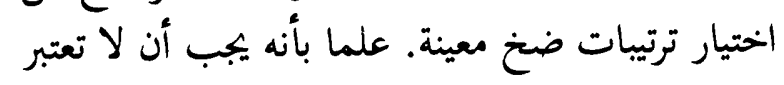
هذه المعادلة الرياضية هى المعادلة النهائية لطبقة المنجور

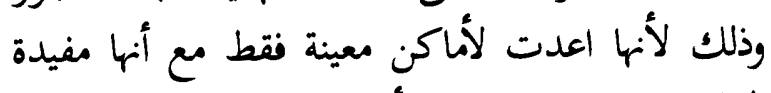

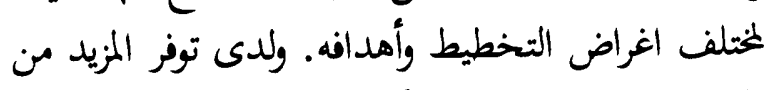

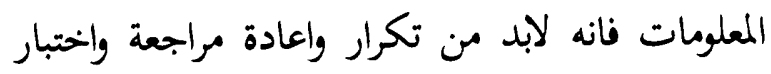
المعادلة الرياضية .

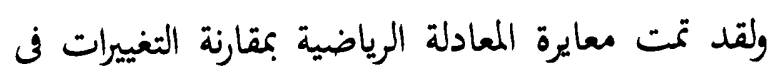
مستويات الماء التى حسبت بواسطة المعادلة الرياضية

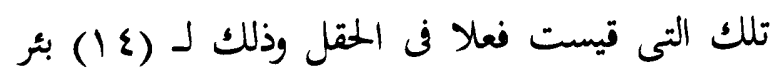

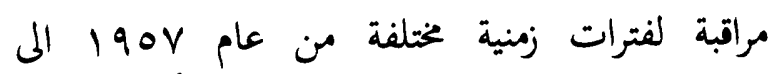

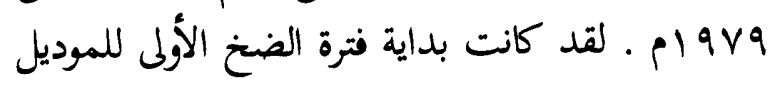

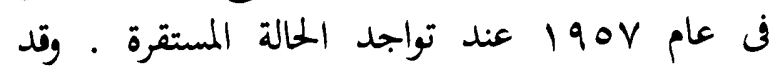

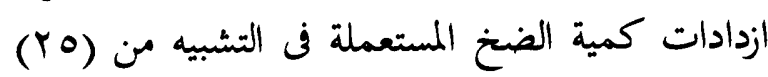

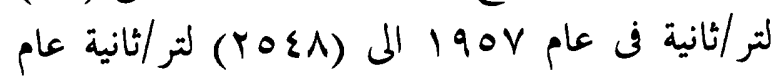
. pl9v9 هذا وان التشبيهات التنبوية تدل على انه اذا استغل

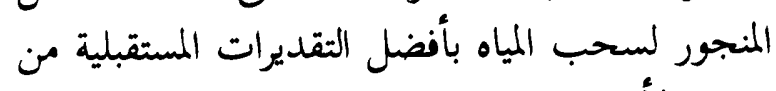

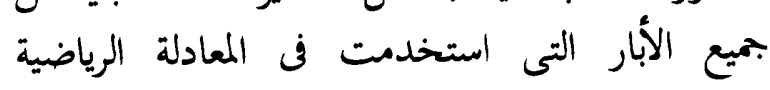

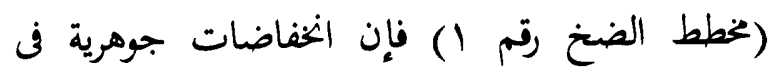

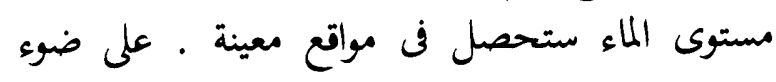

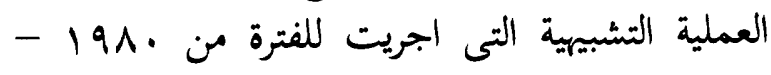

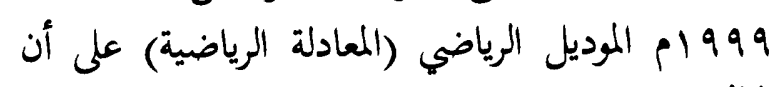
الانغفاض في مستوى الماء في الرياض سيكون حوال

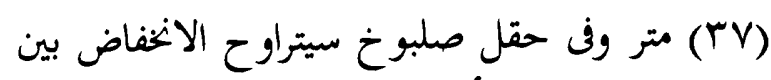

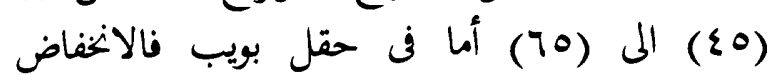




\section{تغيرات مستوى الماء في طبقة المنجور المائية}

\section{الختسبة بالكومبيوتر}

منطقة الرياض - المملكة العربية السعودية بائرومئر

\section{إعـداد}

جيمس إف. وليامز ^ وابراهيم الصقعييى

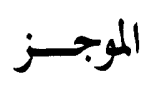

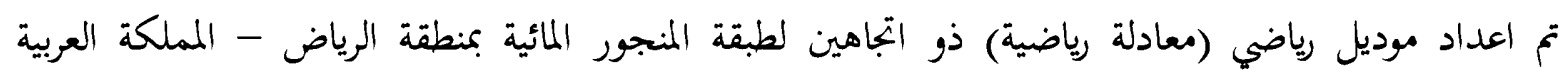

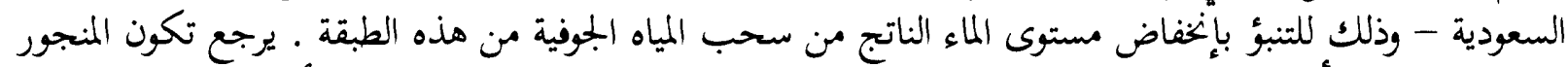

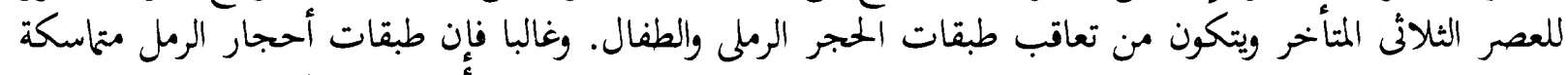

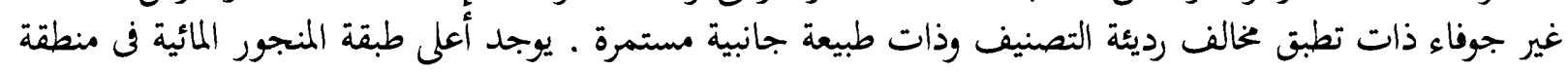

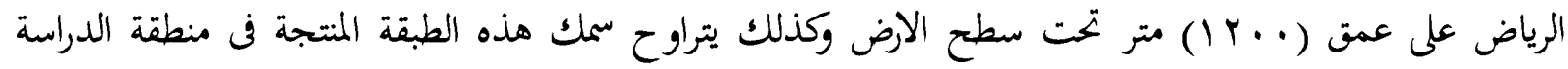

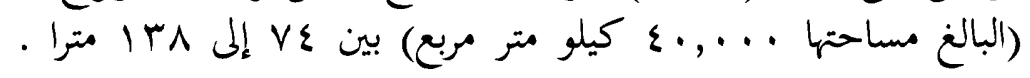

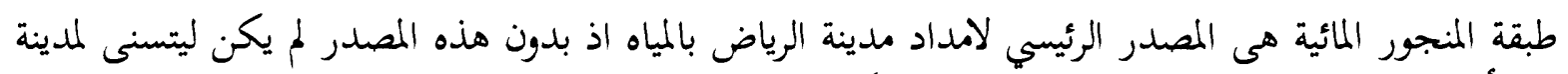

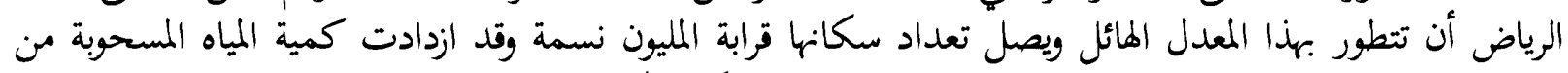

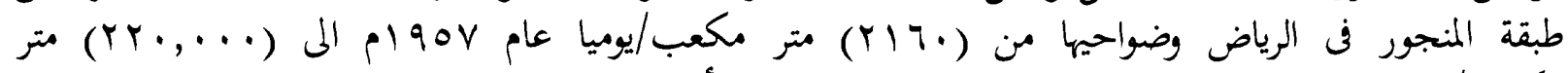

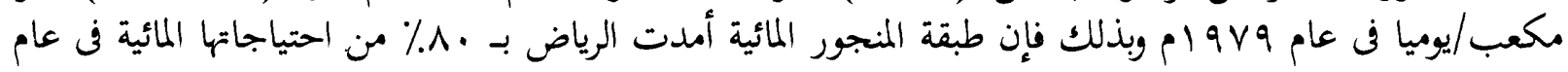

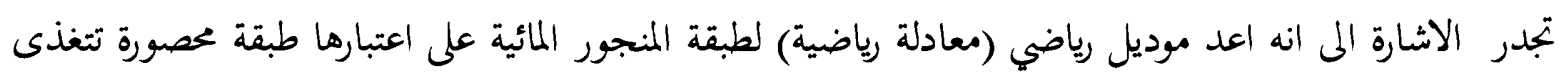

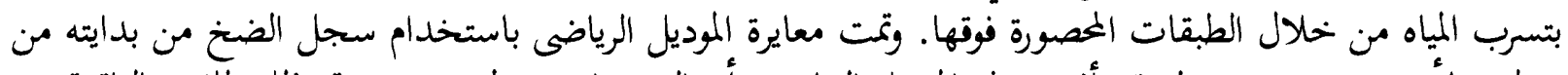

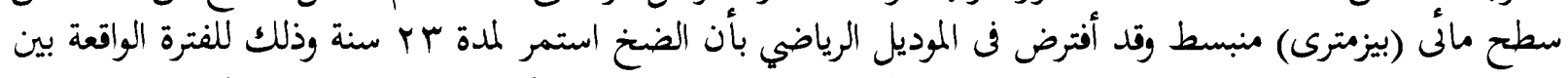

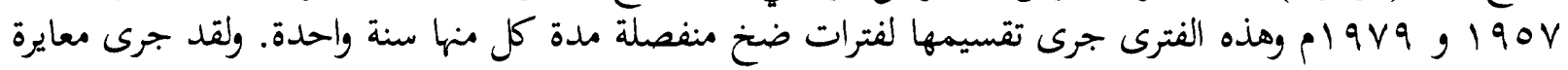

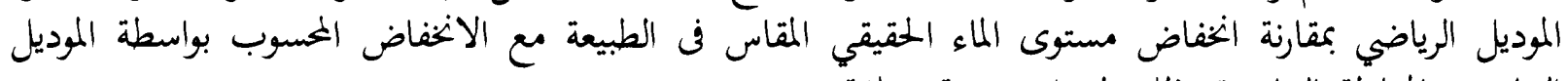

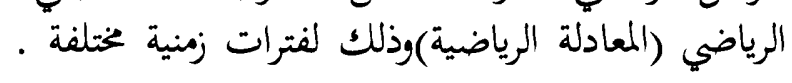

تبلغ قيم وخصائص طبقة المنجور المائية المستعملة في المعادلة الرياضية لمنطقة الدراسة والبالغ مساحتها

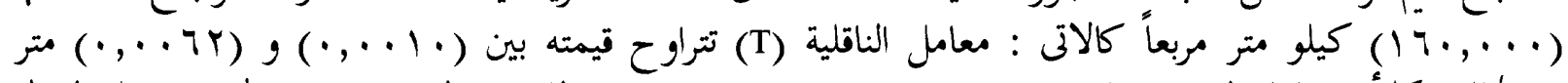

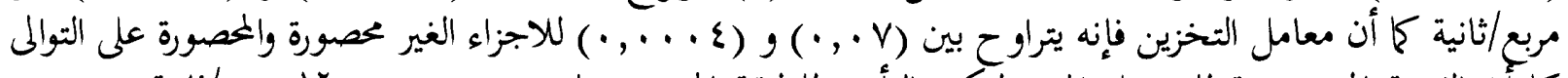

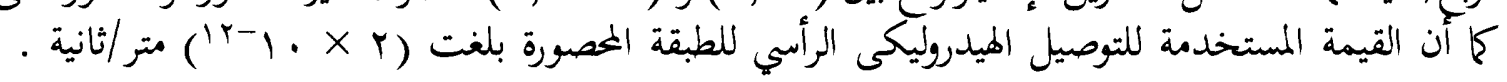

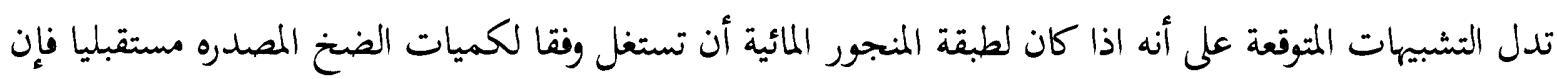

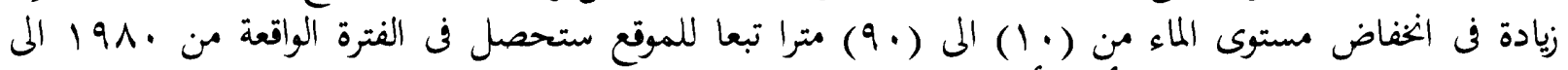

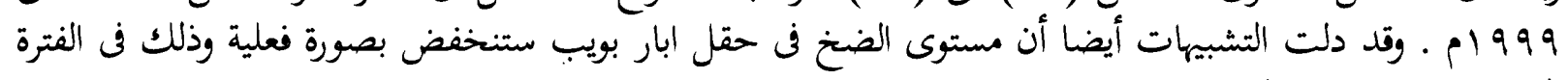

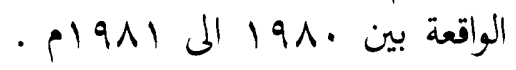




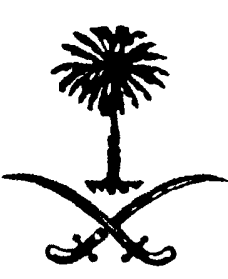

$$
\begin{aligned}
& \text { الململكة المربية السمودية } \\
& \text { وزارة الزراعة والمياه }
\end{aligned}
$$

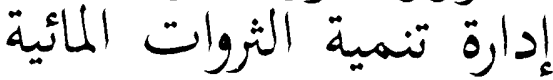

$$
\begin{aligned}
& \text { مصطفى نـورى - المدير العام }
\end{aligned}
$$

السلسلة رقم ץ من الدراسات المائية

تغيرات مستوى الماء في طبقة المنجور المائية

الختسبة بالكومبيوتر

منطقة الرياض - المملكة العربية السعودية

$$
\text { أعده }
$$

جيمس ف. وليامـز الثالث 6 ابراهيم الصقعبي

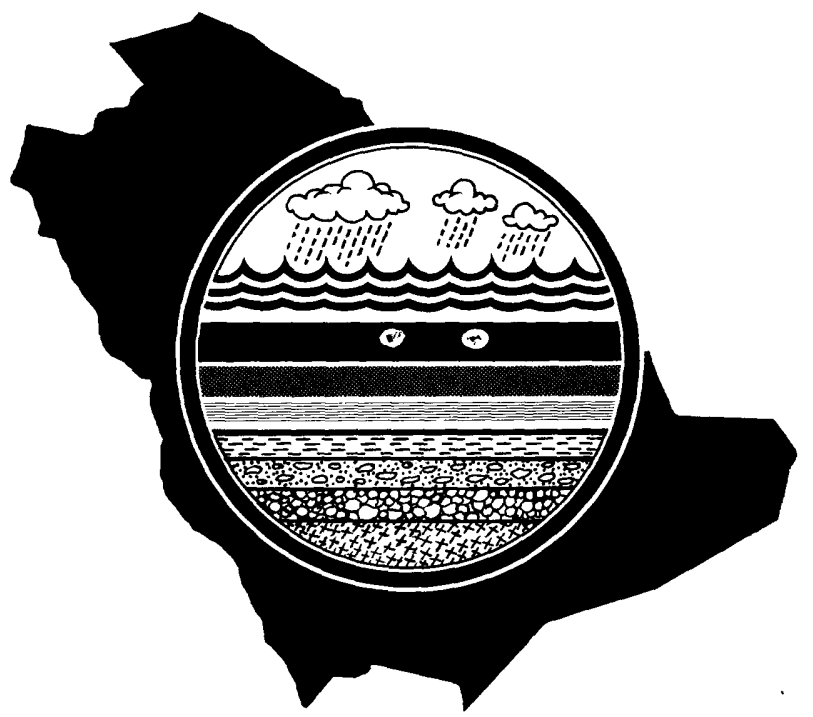

بالعاون مع اللجنة الأمريكية السعودية الاقتصادية المشتركة 